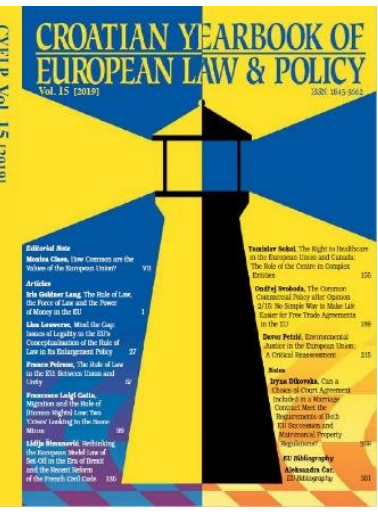

Department of European Public Law

Faculty of Law - University of Zagreb

\title{
Croatian Yearbook of European Law and Policy
}

ISSN 1848-9958 (Online) | ISSN 1845-5662 (Print)

Journal webpage: https://www.cyelp.com

\section{The New EU Space Regulation: One Small Step or One Giant Leap for the EU?}

Luka Orešković and Sonja Grgić

Suggested citation: L Orešković and S Grgić, 'The New EU Space Regulation: One Small Step or One Giant Leap for the EU?' (2021) 17 CYELP 77.

DOI: $10.3935 /$ cyelp.17.2021.454

○ https://www.cyelp.com/index.php/cyelp/article/view/454

https://orcid.org/0000-0003-0068-8290, https://orcid.org/0000-0002-0802-3288

(a) 2021 The Author(s)

算 Submit your work to CYELP
鰦 Published by University of Zagreb

蹒 Published online: 30 November 2021

\section{OPEN ACCESS}

All users are permitted to read, download, copy, distribute, print, search, or link to the full texts of this article, or use it for any other lawful purpose, provided the author(s) are properly acknowledged and cited.

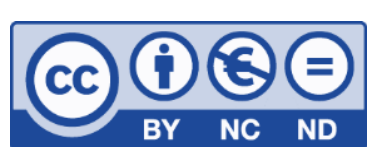

This work is licensed under the Creative Commons Attribution - Non-Commercial - No Derivatives 4.0 International License. This permits anyone to copy and redistribute their work in any medium or format for non-commercial purposes provided the original work and source are appropriately cited.

More information about the journal and submission process can be found at https://www.cyelp.com/index.php/cyelp/about 


\title{
THE NEW EU SPACE REGULATION: ONE SMALL STEP OR ONE GIANT LEAP FOR THE EU?
}

\author{
Luka Orešković and Sonja Grgić*
}

\begin{abstract}
The paper analyses the new push for stronger initiative from the EU in space-related activities, motivated by the new Regulation (EU) 2021 /696, or the EU Space Regulation. The EU took its first steps in this area around the turn of the century, but tangible progress has in reality largely been made in the last decade. Although the EU's Space Programme is at a comparable level with other countries leading in the global space industry, the public is still largely unfamiliar with it. The paper therefore tries to analyse the Programme through its legal and technical aspects in order to explain the EU's activities in the main areas of today's space-related activities - communication, the monitoring of the Earth and its surroundings, as well as different location-based services. In order to highlight the opportunities which are open to every Member State thanks to the new Regulation, a short overview of Croatia's activities thus far in the space industry is given. Although the Regulation is a substantial document, some questions are still left open, such as Member States' liability regarding the Space Programme, and these are discussed in the third part of the paper. The paper concludes by answering the question posed in the title whether this new Space Policy can actually bring the EU to the forefront of one of today's fastest growing sectors.
\end{abstract}

Keywords: space industry, EU Space Programme, Galileo, EGNOS, Copernicus, Space Situational Awareness, GOVSATCOM, FERSAT, Adriatic Aerospace Association

\section{Introduction}

Space-related activities, an ever-growing sector in today's technology-dependent industry, have become the focus of scientific research of many countries in the last few decades. ${ }^{1}$ Accordingly, there was a strong

\footnotetext{
" Luka Orešković, Faculty of Law, University of Zagreb (ORCID iD: 0000-0003-0068-8290) and Sonja Grgić, Full Professor in the Department of Communication and Space Technologies, Faculty of Electrical Engineering and Computing, University of Zagreb (ORCID iD: 0000-0002-0802-3288). DOI: 10.3935/cyelp.17.2021.454.

${ }^{1}$ Cooperation between the private and public sector is one of the space industry's main characteristics, enabling rapid growth which is showing no signs of slowing down. It is estimated that this industry will become a USD 1.4 trillion (or EUR 1.18 trillion) market by 2030 , meaning it will triple in value in just about 10 years, being worth almost the same as the global tourism sector today, albeit much more resistant to external obstacles, such as the COVID-19 pandemic. See Michael Sheetz, 'Bank of America Expects the Space Industry
} 
need for legislative action at the EU level in order to catch up with other global actors. Making slow progress over the last two decades (with most of the work actually being done in the last decade), in 2021 a new Regulation $^{2}$ was finally adopted, creating a stronger basis for the further development of the EU's Space Programme, as well as finally formally adopting the EU Space Policy and Programme. Officially, the beginning of the EU Space Policy can be traced to 2016, when the Council welcomed a so-called 'Space Strategy for Europe', ${ }^{3}$ which had in reality begun to form much earlier, through the creation of different agencies and space programmes, which will be discussed later in the paper. ${ }^{4}$

Joint cooperation in the creation of a common EU Space Policy is no easy task. As far as there is a need for a greater degree of integration, ${ }^{5}$ history has shown that reality is far from the ideals described in the works of many authors: stumbling blocks, usually of a political nature, prevent optimal outcomes, even if they are backed by completely rational arguments. ${ }^{6}$ Knowing all of this, the new Regulation can be seen as a breakthrough, marking a point from which the EU will finally be able to take action at a satisfactory level, and become one of the global centres for the newly formed industry. On the other hand, although the adoption of the Regulation is rightfully seen as an improvement, we should first

to Triple to a \$1.4 Trillion Market within a Decade' (CNBC, 4 October 2020) <www.cnbc. com/2020/10/02/why-the-space-industry-may-triple-to-1 point4-trillion-by-2030.html> accessed 4 August 2021.

${ }^{2}$ Regulation (EU) 2021/696 of the European Parliament and of the Council of 28 April 2021 establishing the Union Space Programme and the European Union Agency for the Space Programme and repealing Regulations (EU) No 912/2010, (EU) No 1285/2013 and (EU) No 377/2014 and Decision No 541/2014/EU [2021] OJ L170/69 (hereinafter: EU Space Regulation).

${ }^{3}$ Commission, 'Space Strategy for Europe' (Communication) COM(2016) 705 final $<$ https: // data.consilium.europa.eu/doc/document/ST-13758-2016-INIT/en/pdf> accessed 4 August 2021.

${ }^{4}$ For the timeline of the EU Space Policy, see <https://www.consilium.europa.eu/en/policies/eu-space-programme/timeline/> accessed 4 August 2021.

${ }^{5}$ Indeed, there have been cooperative difficulties in other spheres of European integration as well, areas which we can undoubtedly say are much more adapted to this type of cooperation. For example, the internal market is probably the greatest achievement of European integration, but is a product of almost 70 years of constant slow development. For a detailed analysis of different aspects of the internal market, see Tamara Ćapeta and Iris Goldner Lang (eds), Pravo unutarnjeg tržišta Europske unije (Narodne novine 2021).

${ }^{6}$ The main obstacle for a common policy in space activities is the large amounts of money needed to establish the appropriate infrastructure and ultimately to make a profit. Since the benefits of space programmes are usually not as visible, at least not at first glance, as those of other areas of economic activity, such as the creation of new machines for factory production, it is hard to justify the huge sums of money needed for its adoption to the general public, the ultimate sources of funding. This, however, as stated previously, is changing due to the recent involvement of private sector subjects in this area. For the problem of democratic justification of the EU Space Programme, see Part 2, 'The EU's space policy: the historical context'. 
analyse whether the Regulation even lives up to expectations, and, secondly, wait for the effects of its implementation, since law and its application are not the same thing.

Academic research of the legal nature regarding the EU's space-related activities is so far almost non-existent, despite the EU's previous regulatory efforts, which causes two types of problems. From the theoretical aspect, the lack of scientific discussion slows the adoption of new regulatory solutions in an area of law which is still largely open for change, or results in unsatisfactory temporary solutions. From the practical aspect, this constant trailing behind of the legal framework prevents the adoption of new technologies, which slows progress, but also opens the possibility of different kinds of abuse. Therefore, the aim of the paper is to discuss all the assets and liabilities of the EU Space Regulation, meaning the EU Space Programme, in order to see in which direction the EU is heading, and whether this direction is even what the EU needs. Since many authors have previously described the theoretical aspects of future space endeavours (mostly currently unachievable) from the legal perspective (that of international law to be more precise), this paper will attempt to provide proposals in the form of concrete regulatory solutions which the EU needs to adopt as soon as possible to compete with ever-increasing international competition, referencing certain historical developments and concepts where necessary.

The paper will be divided into the following parts. First, we will give a short overview of the EU's efforts in creating a space policy. Then, we will study the components of the EU Space Programme - Galileo and EGNOS (jointly known as E-GNSS), Copernicus, Space Situational Awareness (SSA), and Governmental Satellite Communications (GOVSATCOM), relying on the legal basis provided by the EU Space Regulation, but we will also try to provide information of a technical nature. The next part of the paper will be concerned with the opportunities and options for the Member States opened up by the new Regulation, through the example of Croatia, as one of the smallest Member States, but one with significant potential, especially considering human resources. The third part will deal with the Regulation's imperfections, or, more precisely, issues which are still not regulated at all, or not sufficiently so, which will certainly need to be covered by new legislative activity later down the road. Finally, in the conclusion, we will give our opinion on the EU and its partners' efforts in space activities at the legislative and technical level.

\section{The EU's space policy: the historical context}

Before we consider the legal framework currently in force, we need to briefly analyse the EU's efforts in space-related activities in general, which have taken place over the last few decades. 
One of the crucial problems inherent in any activity in space is the 'invisibility' of the return value, or the return of investment. Most people are of the view that investing in the space industry is a waste of money, since the programmes are extremely expensive, while not having a significant impact on the average person's everyday life. This belief most likely stems from the disappointment created by the Space Race of the Cold War, which peaked in the USA's 1969 moon landing, and whose main goal was, in simple terms, nothing more than a country's wish to put on display its power, while the scientific goals were a necessary addition, inasmuch as there was a need for a higher goal, one which would benefit the whole humanity. Although we can say that this has changed, it is far from an irreversible process, especially since the entrance of the private sector in the industry. A prime example is the recent space flights of Jeff Bezos and Richard Branson, the founders of Amazon and Virgin Galactic, respectively. ${ }^{7}$ They both went into space within a week of each other, with basically the same goal - promoting their companies, Blue Origin and Virgin Galactic. ${ }^{8}$ They have achieved nothing except the promotion of their USD 250,000 commercial space flights. This promotion is of a wholly opposite kind to what public space programmes are striving for. In this sense, the involvement of the private sector can be seen as a double-edged sword. Public space programmes strive for tangible results, such as facilitating and accelerating communication, improving geolocation, things which the average person uses daily without even realising it. Action consequently needs to be taken so that people can become aware of all the benefits that space-related activities bring to our day-to-day lives. ${ }^{9}$

Therefore, the popularisation of space policy is what modern countries (or any other subject involved in this area, in our example the EU) need in order to secure funding for the aforementioned programmes, since the money comes from people, as taxpayers. The concept of the

\footnotetext{
${ }^{7}$ Some go so far as to name the competition between these two, as well as Elon Musk, the founder of SpaceX, the 'billionaire space race'. See Ashlee Vance, 'The Future of Space Is Bigger Than Jeff Bezos, Richard Branson, or Elon Musk' (Bloomberg, 16 July 2021) <www. bloomberg.com/news/articles/2021-07-16/billionaire-space-race-between-bezos-branson-and-musk-is-just-the-beginning> accessed 5 August 2021.

${ }^{8}$ Henry Mance, 'Branson, Bezos and the Pointless Billionaire Space Race' Financial Times (London 16 July 2021) <www.ft.com/content/b495e39d-97f6-4cc4-9566-a39f16a57ea0> accessed 5 August 2021.

${ }^{9}$ Although the goal of space exploration is primarily finding new planets or lifeforms similar to us, this has not yet been achieved. So far, space exploration has proved beneficial mostly by making the life on Earth easier - through the ease of communication and speed of news. Therefore, although we undoubtably need to place more importance on the regulation of extra-terrestrial conquest than we are doing today, this paper will focus on the regulation of activities which have a significant impact on our lives right now and in the near future, such as satellites and satellite communication.
} 
popularisation of the EU Space Policy is not only the popularisation of the technology or space itself, but, as Oikonomou believes, something that can more broadly be defined as 'a process of transformation of a complex set of social relations and interests into a coherent, easily understandable and approachable message favouring these interests', meaning the popularisation of this type of approach to economic and social development through participation in space activities. ${ }^{10}$ The same author identifies some methods used by the EU so far to achieve this popularisation: 1) expert groups; 2) the European Security Research \& Innovation Forum (ESRIF); 3) the report by PriceWaterhouseCoopers on the socio-economic benefits of Copernicus; 4) European Space Expo; 5) the process of renaming the GMES to Copernicus. ${ }^{11}$ The ultimate goal of all these actions is the legitimisation, in a natural way, of the EU's efforts in first forming, and then adopting, a space policy. ${ }^{12}$

This popularisation started in the 1990s, with the STAR 21 report of $1992,{ }^{13}$ but was far from the creation of a common space policy. Sigalas argues that the theory of historical institutionalism can also be considered as the correct approach to the process of creating an EU Space Policy. The Policy was not created instantaneously with the Member States suddenly realising its benefits, but rather slowly, over a couple of decades (the Parliament vouched for such a policy as early as the 1970s). ${ }^{14} \mathrm{He}$ also finds that one of the most important external events which resulted in more serious consideration for the EU to create its own programmes was the Kosovo War of 1999, when US military forces blocked civilian GPS signals during their operations. This caused many aviation-related problems and convinced European leaders that global navigation satellite systems (GNSS) were too important to be left to the USA's discretion (referring to the Global Positioning System, or GPS, which is a GNSS developed by the US military). ${ }^{15}$ This resulted in the creation of Galileo, a European GNSS. ${ }^{16}$

\footnotetext{
${ }^{10}$ Iraklis Oikonomou, “'All U Need Is Space”: Popularizing EU Space Policy' (2017) 41 Space Policy 5, 6.

${ }^{11}$ Oikonomou also emphasises the monetary aspect of popularisation: 'And quantification, in the form of benefits measured in euros, is indeed a powerful tool of popularization. Citizens can rest assured that whatever the space industry talks about translates into a tangible, monetized benefit'. ibid, 6-9.

12 ibid, 6.

13 ibid, 6 .

${ }^{14}$ Emmanuel Sigalas, 'Explaining the Rise of the European Union Space Policy: A Theoretical Introduction' (2015) 14(3) The Aviation \& Space Journal 25, 32.

15 ibid, 32.

${ }^{16}$ For more on Galileo, see Part 3.2.1 'E-GNSS - Galileo and European Geostationary Navigation Overlay Service'.
} 
One of the first real steps taken by the EU regarding space activities was the creation of the Galileo Joint Undertaking, or the GJU, set up in May 2002, as cooperation between the European Community and the European Space Agency (ESA) ${ }^{17}$ to manage the development phase of the Galileo programme. The European GNSS Supervisory Authority (GSA) was established as a Community Agency on 12 July 2004 by Council Regulation (EC) 1321/2004, replacing the GJU. It did not take on all of the GJU's functions immediately, but did so three years later, in 2007. Regulation (EU) No 912/2010, which entered into force on 9 November 2010, and which was then amended by Regulation (EU) No 512/2014 of 16 April 2014, restructured the GSA into an agency of the European Union, named the European GNSS Agency (still abbreviated to GSA, perhaps causing some confusion). ${ }^{18}$

In 2007, two important events happened. Galileo's private-public partnership failed, resulting in a dilemma for the Union - either abandon the programme completely, losing all the invested money and benefits of the programme, or fund Galileo exclusively from the Union budget. ${ }^{19}$ Of course, the second option was chosen. The other important event was the adoption of the Lisbon Treaty, which explicitly stated that the EU needs to adopt a European space policy. Article 189 TFEU in this sense states that to achieve this goal, the EU 'may promote joint initiatives, support research and technological development and coordinate the efforts needed for the exploration and exploitation of space' while also 'establish[ing] the necessary measures, which may take the form of a European space programme'. ${ }^{20}$ The Treaty also emphasises the possibility of cooperation with ESA. ${ }^{21}$ According to the Lisbon Treaty, the ESP is in the shared competences of the EU and Member States, with the main EU bodies in this area being the Commission and the Council. ${ }^{22}$ Article 189 does,

\footnotetext{
${ }_{17} \mathrm{ESA}$ is not an agency of the EU, but an intergovernmental organisation created in 1975, and which currently has 22 Member States, but also other so-called Associate Members and Cooperating States in Europe, and also elsewhere (Canada). Although it is not an organisation of the EU, it cooperates with the EU in almost every aspect of EU Space Policy from even before the policy was adopted. For an infographic containing some basic information on ESA, see <https://esamultimedia.esa.int/docs/corporate/This_is_ESA_EN_LR.pdf> accessed 26 November 2021. For a deeper analysis on the difference between ESA and the EU, and their cooperation, see Francis von der Dunk, 'European Space Law' in Francis von der Dunk and Fabio Tronchetti (eds), Handbook of Space Law (Elgar Publishing 2017).

${ }^{18}$ EUSPA <https://www.euspa.europa.eu/about/about-euspa> accessed 6 August 2021.

19 Sigalas (n 14) 32-33.

20 Treaty on the Functioning of the European Union [2016] OJ C202/1, Art 189.

${ }^{21}$ ibid, Art 189.

${ }^{22}$ Kateřina Kočí, Alexandra Madarászová, Miloslav Machoň, 'Examining the EU Actorness: Code of Conduct for Outer Space Activities' in Artur Adamczyk and others (eds), Promoting Values, Stability and Economic Prosperity in the Changing World in the Global Context: The EU Facing Current Challenges, Opportunities, Crisis \& Conflicts (Elipsa 2019) 26, 27.
} 
however, present a limitation on the EU's future space endeavours, since it clearly states that the measures taken by the competent EU authorities exclude the harmonisation of national laws. ${ }^{23}$ This means that the EU's Space Programme cannot replace national space programmes - they can only coexist. Therefore, unless there is a Treaty change, Member States will still be able to develop their space programmes independently, but will participate in a common EU one, mostly through its financing.

The very next year, the Council of the EU published a draft of the Code of Conduct for outer space activities. ${ }^{24}$ Concrete solutions proposed by the draft are these: 1) the creation of a consultation mechanism, which would, however, be created at a later date - the draft only establishes its main purposes; 2) a biennial meeting of Subscribing States, where decisions would be taken by consensus; 3) a central point of contact; and 4) an Outer Space Activities Database. However, even these proposals are practically left at just the most basic levels. Although the Code might have seemed a significant step in the right direction, Annex I of the draft insisted that participation in the Code would be on a voluntary basis with the goal being the participation of as many countries as possible, through a text acceptable to the greatest number, including non-Member States. What should we make of this approach? On one hand, this 'weaker' approach, which aims to satisfy as many countries as possible, as well as not making participation obligatory (since it is difficult to imagine that countries would participate significantly in something which would limit their sovereignty in space-related activities), strives to create at least a common policy for all Member States, and possibly even more broadly (aiming mostly at EU membership candidates), and therefore finally making some tangible progress. On the other hand, these proclamations, without effective proposals, do not actually achieve anything. They just make it seem that something is being done, while in reality nothing is actually achieved (the approach is famously known as the science of 'muddling through'). ${ }^{25}$ This kind of approach can also be seen in the language used - eg the mechanism for notifications would work by a State notifying all other potentially affected States to the 'greatest extent feasible and practicable', ${ }^{26}$ which opens up a significant area for potential excuses without actual support. Finally, the document is only a draft - the Code has still not been accepted, and there have not been

\footnotetext{
${ }^{23}$ TFEU, Art 189(2).

${ }^{24}$ The draft of the Code is available at <https://data.consilium.europa.eu/doc/document/ ST-17175-2008-INIT/en/pdf> accessed 6 August 2021.

${ }^{25}$ The 'science of muddling through' is a term coined by Charles E Lindblom in his paper of the same name. See Charles E Lindblom, 'The Science of "Muddling Through"' (1959) 19(2) Public Administration Review 79.

${ }^{26}$ Draft of the Code of Conduct for outer space activities, para 6.1.
} 
any new pushes for its adoption. The analysis of the Code shows that the EU has acted in a way which was not sufficiently persuasive. Although the EU tried to establish itself as a global leader in this area, it ultimately failed in this goal, due to its inadequate approach.

In the following period, programmes which would later become components of the EU Space Programme were established and started functioning. ${ }^{27}$ Since they are now regulated by the new EU Space Regulation, which replaced the previous legal framework, there is no need to analyse them separately. Therefore, we will only refer to them when necessary in order to assess the new Regulation's potential improvements. Concerning other legal documents adopted in the same period, they were mostly soft law acts, such as strategies. Since they are of significantly lesser importance in comparison with the aforementioned Regulation, we will not analyse them, but rather move on to the current legal regime of the Programme. ${ }^{28}$

\section{EU Space Regulation - the legal basis sufficient for a global leader?}

Regulation (EU) 2021/696 established two very important things the Union Space Programme (for the duration of the Multiannual Financial Framework, or the long-term budget 2021-2027) and the European Union Agency for the Space Programme (EUSPA). ${ }^{29}$ It was adopted by the Parliament and the Council on 28 April 2021, finally creating a uniform and clearer regulation of the space programme and policy. ${ }^{30}$

\footnotetext{
${ }^{27}$ The legal basis for their creation and functioning were Regulations establishing the Galileo and Copernicus programmes, the European GNSS Agency, and a Decision establishing the SST. See Regulation (EU) No 912/2010 of the European Parliament and of the Council of 22 September 2010 setting up the European GNSS Agency, repealing Council Regulation (EC) No 1321/2004 on the establishment of structures for the management of the European satellite radio navigation programmes and amending Regulation (EC) No 683/2008 of the European Parliament and of the Council [2010] OJ L276; Regulation (EU) No 1285/2013 of the European Parliament and of the Council of 11 December 2013 on the implementation and exploitation of European satellite navigation systems and repealing Council Regulation (EC) No 876/2002 and Regulation (EC) No 683/2008 of the European Parliament and of the Council [2013] OJ L347; Regulation (EU) No 377/2014 of the European Parliament and of the Council of 3 April 2014 establishing the Copernicus Programme and repealing Regulation (EU) No 911/2010 [2014] OJ L122; Decision No 541/2014/EU of the European Parliament and of the Council of 16 April 2014 establishing a Framework for Space Surveillance and Tracking Support [2014] OJ L158. All of these were replaced by the EU Space Regulation.

${ }^{28}$ For these strategies and communications of the Commission, see $<$ https://www.consilium.europa.eu/en/policies/eu-space-programme/timeline/> accessed 6 August 2021.

${ }^{29}$ EU Space Regulation, Art 1.

${ }^{30}$ Although the Regulation was adopted in April, it was retroactively applied from 1 January 2021. See ibid, Preamble, para 130.
} 
The Regulation once again emphasises the importance of the EU's competitiveness on the global scene. The Parliament and the Council consider the EU's space industry as one of the most competitive in the world at the moment, but they also recognise that, due to space being an ever-changing industry, new action needs to be taken. ${ }^{31}$ It is also acknowledged that certain Member States do have considerable experience in space-related activities, but that there is a need for actions to develop capacities across the Union and to promote collaboration in all Member States, ${ }^{32}$ as well as with other subjects at the international level (such as the relevant bodies and organisations of the United Nations). ${ }^{33}$

As stated previously, the Regulation establishes the Space Programme and the EUSPA. In the next subsection we will take a closer look at the new Space Programme. Although the Regulation also establishes the regulatory framework for the EUSPA, due to many technicalities regarding, for example, its organisation, decision making and such, and in order not to overfill the paper with too much information, we will not analyse the Agency's legal framework in a separate subsection but will rather refer to relevant provisions when necessary, to help in the understanding of the new Regulation in a more complete manner. Later, a separate section will focus on the Regulation's deficiencies, so that we can give our assessment of the Regulation's impact on the future of the Union's space activities in the conclusion.

\subsection{The European Union Space Programme}

The Regulation establishes the main aspects of the Programme its main principles and objectives, ownership of assets, budgetary and financial questions, governance, and, of course, its components..$^{34}$ In the next few subsections we will take a look at all of these segments, except for the Programme's components, which, due to their importance, will have their own section.

\footnotetext{
31 Therefore, for the Union to remain a leading international player with extensive freedom of action in the space domain, it is crucial that it encourages scientific and technical progress and supports the competitiveness and innovation capacity of space sector industries within the Union (...)'. See ibid, Preamble, para 1.

32 ibid, Preamble, para 10.

33 ibid, Preamble, para 12.

${ }^{34}$ The Regulation also includes detailed provisions on the security of the Programme. The provisions establish a procedure whose main goal is to ensure the security of data and the Programme, as well as different risk assessment procedures. This, however, does not differ greatly from similar procedures in other Union activities, meaning they are not as strictly connected with the space sector itself. Therefore, we will not analyse this segment of the Regulation in this Paper but will only refer to relevant articles. See ibid, Arts 33-43.
} 


\subsubsection{Aims of the programme}

The Programme in general aims to gather and provide, without interruption, high quality and up-to date data, maximise economic and social benefits through the encouragement of start-ups, enhance the security and safety of the Member States and the Union as a whole, but also the safety and security of outer space activities, and promote the Union as a leading global actor in the space sector. ${ }^{35}$ All of these goals are not unique to space-related activities - this approach is now utilised by the EU in all areas of economic activity, but can generally be considered as a leading approach in today's world. The EU also promotes the further development of space technologies, primarily those helping to create more efficient space launch systems, for the use of not only the Union, but also for Member States and international organisations. ${ }^{36}$ Especially important is the fact that all activities in support of an innovative and competitive Union space sector (such as building a coherent, business-friendly ecosystem by creating a network of space hubs) need to be conducted in such a way that it provides equal opportunity for all Member States to participate in the Programme, ${ }^{37}$ which is in accordance with the now generally accepted principle (in international law) that all countries need to be able to access space, as well as with the equality of all Member States (of the EU).

\subsubsection{Governance of the Programme and the ownership of its assets}

Governance of the Programme is entrusted to multiple subjects the Union itself (or rather certain of its institutions - the Commission and the EUSPA), Member States (the countries themselves, but also certain Member State organisations ${ }^{38}$ which have been determined by the Member States themselves), the European Space Agency (ESA), the European Organisation for the Exploitation of Meteorological Satellites (EUMETSAT), and other entities. Regarding Member States, there is no obligation for their participation in the Programme ('The Member States may participate in the Programme'), but there is an obligation to take all measures which are necessary for ensuring the smooth functioning of the Programme. ${ }^{39}$ Their participation can include their contributions through technical competences, know-how and assistance, but also by making available to the EU information, services and infrastructure

\footnotetext{
35 ibid, Art 4(1).

${ }^{36}$ ibid, Art 5.

37 ibid, Art 6.

38 ibid, Art 27(2).

39 ibid, Art 27(1 and 4) (emphasis added).
} 
owned by them, or those that are located on their territory, ${ }^{40}$ which is now an integral part of the obligations stemming from EU membership. The Commission is responsible for the Programme's implementation, and this responsibility includes determining the priorities and long-term evolution of the Programme, supervising its implementation, managing its components, regulating the division of tasks between entities involved in the Programme, coordination of the Programme, fostering and supporting its development, and ensuring the Programme's coherence..$^{41}$ EUSPA has two kinds of tasks - those which are its own and those which the Commission entrusts to it. Its own tasks include ensuring the security accreditation of all the Programme's components and the undertaking of communication, market development and the promotion of Galileo, EGNOS and Copernicus. ${ }^{42}$ The Commission can entrust different tasks to EUSPA, including managing the exploitation of EGNOS and Galileo, coordination of user-related aspects of GOVSATCOM, and others, but only if they do not result in the duplication of activities performed by other entities within the Programme and if they improve the efficiency of the Programme's implementation. ${ }^{43}$ ESA can also be entrusted with certain tasks, under the condition that the EU's interests are protected. Regarding Copernicus, it can be entrusted with the coordination, implementation and evolution of the space component, the design, development and construction of its space infrastructure and, if appropriate, providing access to third-party data. Regarding Galileo and EGNOS, it deals with the evolution and development of the systems. Finally, it can conduct upstream research and other similar activities in other parts of the Programme, according to its expertise. ${ }^{44}$ ESA can be entrusted with other tasks, under the same conditions required for EUSPA. Certain activities can be entrusted by the Commission to other entities as well, such as EUMETSAT (activities concerned with the Copernicus space infrastructure) but also other agencies and bodies (the European Environment Agency, Frontex, the European Maritime Safety Agency, SATCEN). ${ }^{45}$ It is also important to mention that a financial framework partnership agreement was provided for in the Regulation, which was to define the roles, responsibilities and obligations of the Commission, EUSPA and ESA in their cooperation in activities which are part of the new Space Programme. ${ }^{46}$

\footnotetext{
40 ibid, Art 27(1).

${ }^{41}$ ibid, Art 28.

42 ibid, Art 29(1).

43 ibid, Art 29(2-3).

44 ibid, Art 30(1).

45 ibid, Art 32.

46 ibid, Art 31. The Article also requires that ESA applies the Union security rules, as defined in security agreements concluded between the EU's institutions and ESA, that it takes
} 
After months of negotiations, the agreement was finally signed on 22 June 2021, and marks a step in the right direction in the EU and ESA's cooperation, as well as in achieving one of the main goals of ESA's Agenda $2025 .^{47}$

From the legal perspective, we can say that the Regulation does establish a good framework for different subjects to take part in the Programme. Although the Commission and EUSPA obviously play the most important role, of course in cooperation with Member States, the Regulation provides a significant area of flexibility for the inclusion of other subjects in the Programme. The EU has clearly used this significantly, can be seen from the example of the financial framework partnership agreement with ESA, as well as the Agreement between the EU and ESA on the Implementation of the Copernicus Programme from 2014, which we will touch on below. This cooperation can ensure that the EU's efforts do not go without results.

Generally speaking, the Union owns all the tangible and intangible assets created under the Programme's components. In order to ensure the Union's ownership of these assets, it needs to take care to include the relevant provisions in any contract or agreement it signs. ${ }^{48}$ However, if these assets are a result of grants or prizes fully financed by the Union, or if they are not fully financed by the Union, or if they relate to the development, manufacture or use of PRS receivers incorporating EUCI, or components of such receivers, then the EU does not own these assets. ${ }^{49}$ This does not mean that the Union cannot use them, but the task of the Commission is to ensure their optimal usage, especially when these assets are intellectual property rights. ${ }^{50}$

Here a question can arise regarding the ownership of different satellites launched jointly by the EU and ESA. ESA is, simply put, the EU's operational mechanism for the Programme, which means that the EU uses ESA's technology, most importantly rockets (Ariane 5) ${ }^{51}$ for the launching of satellites into space, as well as for the development of satellites,

appropriate actions in order to ensure the protection of the EU's interests, as well as the establishment of control and monitoring measures.

${ }^{47}$ ESA, 'The EU and ESA sign a new Financial Framework Partnership Agreement' <www. esa.int/Newsroom/Press_Releases/ESA_and_EU_celebrate_a_fresh_start_for_space_in_ Europe $>$ accessed 9 August 2021.

${ }^{48}$ EU Space Regulation, Art 9(1).

49 ibid, Art 9(2).

50 ibid, Art 9(5-6).

${ }^{51}$ Ariane 5, soon to be replaced by Ariane 6, is one of the most reliable launchers in the world, with only a few failures in its more than 100 launches in over around 25 years. See ESA, 'Ariane 5' <www.esa.int/Enabling_Support/Space_Transportation/Launch_vehicles/ Ariane_5> accessed 19 August 2021. 
but then usually governs the Programme without ESA. Legally, this can be clearly seen in the United Nations Register of Objects Launched into Outer Space. Although ESA, and not the EU, submits registration notifications, in one of the notifications which ESA submitted when launching Sentinel-3B, one of Copernicus satellites, ESA explicitly states that:

Pursuant to the Agreement between the European Union (...) and the European Space Agency on the Implementation of the Copernicus Programme, including the Transfer of Ownership of the Sentinels (Copernicus Agreement) (...) ownership of Sentinel-3B was transferred to the European Union at the moment of lift-off of the satellite's launch vehicle. ${ }^{52}$

This can also result in specific solutions regarding liability for potential damage, but this will be discussed in a separate section. ${ }^{53}$ In addition, this shows the flexibility of the approach the EU has taken, since the Regulation states only the goal (ownership of assets), but then allows for different solutions which can later be implemented in cooperation with other subjects. By emphasising adaptability and focusing on the cooperation aspect, the EU has taken the right approach in its goal of becoming a global leader in this area.

\subsubsection{Budget and financing of the Programme}

Concerning the budget, the Parliament and the Council allocated EUR 14.88 billion in current prices for the period from 1 January 2021 to 31 December 2027. The biggest slice of this amount is intended for the Galileo and EGNOS programmes - EUR 9 billion, then for Copernicus - EUR 5.421 billion, and finally, EUR 442 million for SSA and GOVSATCOM. ${ }^{54}$ The Commission still has some discretion, since it can reallocate funds from one component of the Programme to another - it can do this without a special procedure if the reallocated funds do not exceed $7.5 \%$ of the proposed expenditure of the category that provides the funds, and the one that receives it. If, however, the reallocated funds exceed this limit, then an implementing act needs to be adopted in a special procedure. ${ }^{55}$ These funds can also be allocated to Member States under shared management, but can also be transferred to the Programme at the request of a Member State, but will then be used for the benefit of the concerned Member State. ${ }^{56}$ A Member State can also endow the

\footnotetext{
${ }^{52}$ Information Furnished in Conformity with the Convention on Registration of Objects Launched into Outer Space, ST/SG/SER.E/871 <www.unoosa.org/oosa/en/osoindex/ data/documents/esa/st/stsgser.e871.html> accessed 19 August 2021.

${ }^{53}$ See Section 4.1 'Liability - are provisions of international law enough?'.

${ }^{54}$ EU Space Regulation, Art 11(1).

55 ibid, Art 11(2).

56 ibid, Art 11(7).
} 
Programme with additional funds (which will be treated as external assigned revenue) in order to finance additional elements of a Programme, but only if they do not represent a burden on the Programme in any way - once again, the Commission decides this by means of implementing acts. ${ }^{57}$ This flexibility is needed in great part due to the complexity of the Programme, in addition to potential unpredictable developments.

The dominant way of financing ${ }^{58}$ is procurement. Procurement procedures need to be conducted in a way which takes into consideration the widest and most open participation of economic subjects, ensuring effective competition and avoiding reliance on only one single provider, promoting the autonomy of the Union and satisfying the security criteria. ${ }^{59}$ Avoiding relying on a single provider minimises potential risks of different kinds of abuse, and promotes a spirit of cooperation. A special type of contract is the so-called conditional stage-payment contract, which consists of a fixed stage, for which a firm commitment needs to be given by the contractor, and one or more conditional stages, which are conditional in the sense of the budget and performance. ${ }^{60}$ Each stage, however, is a consistent whole which must be executed if the criteria are matched (the fixed stage is the basis of the contract, so there are no additional conditions; for conditional stages, a decision of the contracting authority is needed). ${ }^{61}$ Another type of contract is the cost-reimbursement contract. This can be used in two different cases: 1) when the contract has complex features or which include a significant number of technical risks due to the required use of new technology; 2) when activities subject to the contract must begin immediately, even though an accurate fixed price cannot yet be determined in full, because of significant risks or because the performance of the contract in question is dependent on the performance of other contracts. ${ }^{62}$ Since projects in space-related activities are usually of this nature, due to their complexity and potential technical complications, the frequent use of exactly this type of contract can be expected. The contracting authority decides whether it wishes to utilise a full or a partial cost-reimbursement contract, and, in coor-

\footnotetext{
57 ibid, Art 11(2-3).

${ }^{58}$ For procurement, grants and prizes, the Commission has the ability to apply certain eligibility and participation conditions if it is of the opinion that this is necessary to preserve 'the security, integrity and resilience of the operational Union systems'. These conditions are: 1) the legal entity and its executive management structures need to be established in a Member State; 2) the entity needs to commit to carrying out all relevant activities in one or more Member States; 3) the entity must not be under the control of a third country or third country's entity. These conditions can still be overridden in certain cases. ibid, Art 24 .

59 ibid, Art 14(1).

60 ibid, Art 15(3).

${ }^{61}$ ibid, Art 15(4-5).

62 ibid, Art 16(3).
} 
dination with the contractor, decides on the amount of reimbursement, which includes all direct costs actually incurred by the contractor in performing the contract, indirect costs, a fixed profit and an appropriate incentive fee based on achieving the established goals. ${ }^{63} \mathrm{~A}$ maximum price ceiling also needs to be determined, but it can still be modified in accordance with Article 172 of the Financial Regulation. ${ }^{64}$ In harmony with the Union's aim of staying a global leader in space-related activities, it is necessary to encourage new entrants, small and medium-sized enterprises (SMEs), and start-ups. In order to achieve these goals in the space sector, the contracting authority can request from the tenderer the subcontracting of a part of the contract to companies which do not belong to the tenderer's group. ${ }^{65}$ This is especially important for contracts above EUR 10 million, for which the contracting authority will aim to ensure that at least $30 \%$ of the value of the contract is subcontracted. ${ }^{66}$ This is also in accordance with the aforementioned principle which aims to avoid reliance on only one provider.

Although we can expect procurement to be the most widespread way of financing the different activities of the Programme, there are certain other methods, with different degrees of EU involvement. The Union can cover up to $100 \%$ of eligible costs through grants and prizes. ${ }^{67}$ There are some limitations to this, though. The most important is that these grants and/or prizes cannot exceed EUR 200,000.68 There is also the possibility of assigning grants for pre-commercial procurement and the procurement of innovative solutions, where the contractor will own at least the intellectual property rights attached to the results, while the contracting authorities would 'enjoy at least royalty-free access rights to the results for their own use and the right to grant, or require the contractor to grant, non-exclusive licences to third parties to exploit the results for the contracting authority under fair and reasonable conditions without any right to sub-licence'. ${ }^{69}$ Blending operations can also be conducted. ${ }^{70}$ Another way of financing is cumulative and alternative funding. This can happen when an action which has already received a contribution under

\footnotetext{
63 ibid, Art 16(1-2).

${ }^{64}$ ibid, Art 16(4).

65 ibid, Art 17(1). The tenderer can, however, make a claim for an exemption from the aforementioned request. ibid, Art 17(2).

66 ibid, Art 17(3).

${ }^{67}$ It can do this despite the usual application of the co-funding principle. ibid, Art 18(1).

68 ibid, Art 18(2-4).

69 If the contractor fails to exploit the results within the period stated in the contract, then the contracting authority reserves the right to transfer ownership of the results. ibid, Art 20(1 and 3).

70 ibid, Art 21.
} 
the Programme receives a contribution from another Union programme. This is possible only under the condition that the contributions do not cover the same costs and that the cumulative financing does not exceed the total eligible costs of the action. ${ }^{71}$ Finally, joint procurement can be carried out by the Commission or the EUSPA and the ESA or another international organisation which is involved in the Programme. ${ }^{72}$

Provisions concerning financing are probably the most sensitive segment established by the Regulation. So far, it has proved difficult for different national actors, even leading ones, to secure funding from the EU budget. If we take a look at Regulation (EU) No 1285/2013, ${ }^{73}$ which established the framework for Galileo and EGNOS, but is now replaced by the new EU Space Regulation, we can see many similarities. Almost all the methods of financing previously mentioned were already established as such by the previous Regulation, albeit not in such a detailed or clear manner. There are certain differences, for example, grants and prizes are not mentioned at all in the previous Regulation, but this method of financing is not a significant one, considering the maximum sums of money which can be awarded. This automatically raises doubts about whether this new Regulation can bring any improvement. On the other hand, adopting a new Regulation which establishes common provisions for the whole Programme in one place can be seen as a step forward. It could result in a more transparent and efficient procedure. Since the budget has changed, more money can be given through these methods of financing, thus creating new opportunities. All of this, however, remains to be seen, since the Regulation is still a very new act, although it can be hoped that it will actually be a step forward.

\subsection{Components of the European Union Space Programme}

The Regulation establishes the following components of the Programme (Figure 1): Galileo, European Geostationary Navigation Overlay Service (EGNOS), Copernicus, Space Situational Awareness (SSA), and

\footnotetext{
${ }^{71}$ ibid, Art 22(1). In addition, actions which have been awarded a Seal of Excellence label under the Programme may also receive financial support from the European Regional Development Fund or the European Social Fund Plus, but only if they have previously been assessed, comply with minimum quality requirements, and cannot be financed under a call for proposals because of budgetary restrictions. All of these conditions need to be met cumulatively. ibid, Art 22(2).

72 ibid, Art 23.

${ }^{73}$ Regulation (EU) No 1285/2013 of the European Parliament and of the Council of 11 December 2013 on the implementation and exploitation of European satellite navigation systems and repealing Council Regulation (EC) No 876/2002 and Regulation (EC) No 683/2008 of the European Parliament and of the Council [2013] OJ L347.
} 
Governmental Satellite Communications (GOVSATCOM) ${ }^{74}$ For a clearer view of all these components, we will examine each in a separate subsection.

Figure 1: Components of the Programme <www.horizon-europe-infodays2021. eu/system/files/2021-07/Session07_Info\%20Days\%202021_HEU_ CL4_Destination5_SPACE.pdf> accessed 24 August 2021.

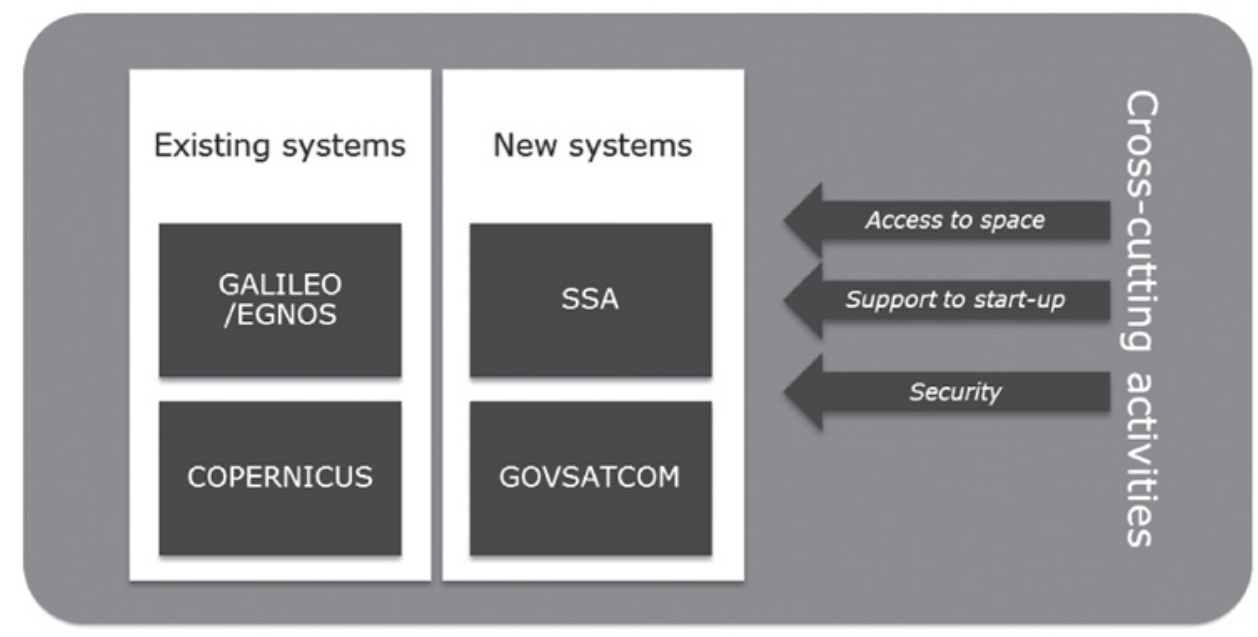

Figure 1 shows the different segments of the EU Space Programme, as established by the new Regulation. As will be discussed in the following subsections, the new Regulation introduced the GOVSATCOM segment, which is completely new, as well as the SWE and NEO sub-components of the SSA segment, which previously consisted of only the SST sub-component.

\subsubsection{E-GNSS - Galileo and European Geostationary Navigation Overlay Service}

\subsection{1.a Evaluation of technical aspects}

The Regulation defines Galileo as an

autonomous civil global navigation satellite system (GNSS) under civil control, which consists of a constellation of satellites, centres and a global network of stations on the ground, offering positioning, navigation and timing services and integrating the needs and requirements of security. ${ }^{75}$

\footnotetext{
74 ibid, Art 3(1).

75 ibid, Art 3(1(b)) (emphasis added).
} 
A GNSS is a group (the terminus technicus is constellation) of satellites which provide signals from space to receivers situated on the Earth's surface, and which carry positioning and timing information, which the receivers then use to calculate location. ${ }^{76}$ Galileo is a relatively new GNSS, whose beginnings can be traced, as explained before, to events happening at the turn of the century. ${ }^{77}$ Along with Galileo, other GNSSs include the NAVSTAR Global Positioning System, or GPS (USA), the Global'naya Navigatsionnaya Sputnikovaya Sistema, or GLONASS, (Russia), and the BeiDou Navigation Satellite System (China). ${ }^{78}$ All GNSSs use medium Earth orbits, ${ }^{79}$ while Galileo specifically places its satellites at an altitude of $23,222 \mathrm{~km}$ and at an inclination of 56 degrees. ${ }^{80}$ At every moment, six to eight satellites will cover most locations, resulting in positioning accurate to within a few centimetres. ${ }^{81}$ The benefits of Galileo can be seen in many different areas of life, such as the Internet of Things (IoT), location-based services (LBS), transport, fisheries, emergency services, and others. ${ }^{82}$

Currently there are 26 satellites in orbit, with the first ones launched in $2011,{ }^{83}$ but three of them are not usable, while one is not available. ${ }^{84}$ This number is not final - there are plans to launch new Galileo satellites. A new generation of Galileo satellites, which would be launched using electric engine propulsion software, and would carry digitally controllable antennas, will be made by Airbus and Thales Alenia Space - the contract itself is worth around EUR 1.5 billion, with the goal of creating 12 satellites in total, the first ones being launched in $2024 .^{85}$

\footnotetext{
76 EUSPA, 'What is GNSS?' <www.euspa.europa.eu/european-space/eu-space-programme/ what-gnss $>$ accessed 10 August 2021.

77 See section 2.

78 EUSPA, 'What is GNSS?' <www.euspa.europa.eu/european-space/eu-space-programme/ what-gnss $>$ accessed 10 August 2021.

79 Tyler Reid, Todd Walter and Per Enge, 'Qualifying an L5 SBAS MOPS Ephemeris Message to Support Multiple Orbit Classes', 26th International Technical Meeting of the Satellite Division of the Institute of Navigation (ION GNSS+ 2013) (Nashville, 2013) 2.

80 EUSPA, Galileo, 'Programme' <www.euspa.europa.eu/european-space/galileo/programme> accessed 10 August 2021.

81 ibid.

82 EUSPA, Galileo, 'Applications' <www.euspa.europa.eu/european-space/galileo/applications> accessed 10 August 2021.

83 ibid.

${ }^{84}$ EUSPA, Galileo, 'Constellation Information' <www.gsc-europa.eu/system-service-status/constellation-information> accessed 10 August 2021.

85 These two companies were given the task of making four pathfinder satellites in 2011 and 2012, but then lost the orders for operational satellites to Germany's OHB-System and UK's Surrey Satellite Technology Ltd. This, however, was broken up due to Brexit, so the EU decided to return to the original creators, after an unsuccessful bid from OHB-System.
} 
This did not go through without controversy, though. On 29 January 2021, the German satellite company OHB System AG brought an action before the General Court of the European Union for the annulment of two decisions of ESA, which acted on behalf of the Commission, by which it rejected OHB's offer in a previously conducted procurement procedure. It also lodged an application for interim relief, whose goal was to suspend ESA's decisions. ${ }^{86} \mathrm{OHB}$, as the applicant, relied on four pleas in law: 1) that the Commission (as the defendant) should have excluded Airbus (as the competitor) from the process of procurement since one of its senior employees previously held a senior position in OHB, which could have led to an unfair advantage for Airbus; 2) Airbus's tender was significantly lower than those of the other tenderers, including OHB; since the Commission did not examine Airbus's tender (which could have led to the exclusion of Airbus from the procurement procedure), it failed to comply with provisions concerning low tenders; 3) connected with the previous plea, Airbus argues that the tender evaluation procedure infringes Article 160(1) of the Financial Regulation (principles of transparency, proportionality, equal treatment and non-discrimination of procurement law); and, finally, that 4) the Commission did not reach an autonomous decision, but rather only followed the opinion of ESA in its preparatory TEB Evaluation Report. ${ }^{87}$ On 26 May 2021, the President of the General Court dismissed OHB's application for interim relief due to: 1) the detrimental effects of the suspension on EU's Space Programme; and 2) ESA's previous request for information to Airbus in order to examine if there had been any illegal activity. ${ }^{88}$ The final judgment in the case (regarding substantive questions) has still not been delivered at the time of writing, but right now it seems very unlikely that the Court will deliver a judgment in favour of OHB. In any case, this will probably be the first judgment of the Court concerning the new EU Space Programme.

There are six Galileo-specific services (those for which Galileo is established) and three to which Galileo contributes. Galileo-specific services are: 1) a Galileo open service (GOS), which provides positioning and synchronisation information used mostly by navigation applications

See Jonathan Amos, 'EU Orders Next-Generation Galileo Satellites' (BBC, 20 January 2021) <www.bbc.com/news/science-environment-55742422> accessed 10 August 2021.

86 Order of the President of the General Court in Case T-54/21R OHB v Commission, Press Release No 90/21, Luxembourg, 26 May 2021 <https://curia.europa.eu/jcms/upload/ docs/application/pdf/2021-05/cp210090en.pdf > accessed 11 August 2021. For more context, see n 85.

87 Case T-54/21 OHB System v Commission: action brought on 29 January 2021.

88 Order of the President of the General Court in Case T-54/21R OHB v Commission, Press Release No 90/21, Luxembourg, 26 May 2021 <https://curia.europa.eu/jcms/upload/ docs/application/pdf/2021-05/cp210090en.pdf $>$ accessed 11 August 2021. At the time of writing, the official full text of the order is available only in German and French. 
for consumer usage; 2) a high-accuracy service (HAS), which provides high-accuracy positioning and synchronisation information used by applications for professional or commercial use; 3) a signal authentication service (SAS), also intended for professional and commercial use; 4) a public regulated service (PRS), used only by government-authorised users, and for sensitive applications; 5) an emergency service (ES), for broadcasting warnings regarding natural disasters or other emergencies; 6) a timing service (TS), providing an accurate reference time. GOS, HAS, ES and TS are free of charge, while PRS is free of charge for the Member States, the Council, the Commission, EEAS and, where appropriate, authorised Union agencies. ${ }^{89}$ Galileo contributes to the search and rescue support service (SAR) of the COSPAS-SARSAT system, integrity-monitoring services, space weather information, and early warning services. ${ }^{90}$

Since GNSSs on their own have some imperfections, they are usually accompanied by augmentation services to optimise their functioning. For Galileo, this is the European Geostationary Navigation Overlay Service, or EGNOS. It is defined as a

civil regional satellite navigation system under civil control which consists of centres and stations on the ground and several transponders installed on geosynchronous satellites and which augments and corrects the open signals emitted by Galileo and other GNSSs, inter alia for air-traffic management, for air navigation services and for other transport systems. ${ }^{91}$

It falls within the category of so-called satellite-based augmentation systems (SBAS), which all function in roughly the same way. If we take EGNOS as an example, the procedure functions as follows: data collected by GNSS (meaning satellites which orbit the Earth) are collected by reference stations deployed across Europe. GNSS data, along with information collected by ground-based reference stations are transferred to a central computing centre, where through the combination of this orbital and ground information, GNSS errors can be noticed and corrected (Figure 2). Then, EGNOS satellites broadcast this information as an overlay to the original GNSS data, thus providing much more precise information to the end user. ${ }^{92}$ In this way, EGNOS provides crucial data to many areas of human activity, such as agriculture; aviation, through better access to small airports and increasing safety (with LPV-200, which is free to use, an aircraft can make a final approach without the need for visual contact with the ground until it is 200 feet above the runway);

\footnotetext{
${ }^{89}$ EU Space Regulation, Art 43(1).

90 ibid, Art 43(2).

${ }^{91}$ ibid, Art 3(1(b)) (emphasis added).

${ }_{92}$ EUSPA, 'What is EGNOS?' <www.euspa.europa.eu/european-space/egnos/what-egnos> accessed 10 August 2021.
} 
maritime activities; road transport; and location-based services, by improving the accuracy of GNSS signals, mostly by reducing the negative impact of the ionosphere on the calculated position. ${ }^{93}$ EGNOS is easily of the greatest importance to the aviation sector. EGNOS improves the precision of GNSS data so that the data can be used for critical flight stages, such as landings. Without EGNOS, GNSS data alone would not meet the standards set by the International Civil Aviation Organisation. ${ }^{94}$

According to the Regulation, EGNOS provides three different types of services, all free of direct user charges. These are: 1) an EGNOS open service (EOS), which is the EGNOS equivalent of Galileo's GOS; 2) the EGNOS data access service (EDAS), which does the same thing as EOS, but is intended mainly for commercial and professional use, and thus offers improved performance and data with greater added value than EOS; and 3) a safety-of-life (SoL) service, which alerts users to any failure in, or out-of-tolerance with, signals emitted by GNSSs which EGNOS augments, mainly concerning users for whom safety is essential (eg the civil aviation sector). ${ }^{95}$

EGNOS only covers the geographical area of the EU Member States. However, its coverage can be extended to other regions, such as territories of candidate countries, third countries in the European Neighbourhood Policy, and third countries associated with the Single European Sky. In these cases, the cost of the extension and functioning of EGNOS will not be covered by the budget of the Programme, but will be financed through other means, as decided by the Commission. ${ }^{96,97}$

\subsection{1.b Comparison of the old and new legal framework}

The question which arises at the end of our overview of Galileo and EGNOS is whether the new Regulation has actually introduced anything new, or has it simply copied the previous legal framework? Well, we have already mentioned that the means of financing are basically the same.

\footnotetext{
93 EUSPA, 'EGNOS Applications' <www.euspa.europa.eu/european-space/egnos/egnos-applications $>$ accessed 10 August 2021.

94 EUSPA (n 92).

95 EU Space Regulation, Art 46(1)

96 EU Space Regulation, Art 46(2-3).

97 A good example is the UK, which left the EU and, subsequently, no longer participates in Galileo or EGNOS programmes. It does not use Galileo for defence or critical national infrastructure purposes; it does not have access to the encrypted PRS; it cannot participate in the development of Galileo or EGNOS; from 25 June 2021 UK users will not be able to use the EGNOS SoL service and EGNOS Working Agreements (EWAs) and UK based subjects cannot bid for future Galileo contracts and may face difficulties in carrying out and completing existing ones. See GOV.UK <www.gov.uk/guidance/uk-involvement-in-the-euspace-programme> accessed 10 August 2021.
} 
Although the names have changed a little ${ }^{98}$ the services provided by EGNOS are still the same three. Galileo has evolved in that aspect, and the new Regulation now explicitly mentions that it provides a timing service and signal authentication service, which were not mentioned in the old Regulation. In addition, HAS was previously described simply as a commercial service, but has since changed its name to emphasise its main characteristic - greater accuracy in comparison to GOS, even though it is still primarily used for commercial purposes. ${ }^{99}$ Since the old Regulation was adopted in 2014, and since new Galileo and EGNOS satellites have been launched, in addition to the planned launches in the future, the new Regulation had to adapt to new technological advances, ${ }^{100}$ but major changes are missing. This, of course, is not necessarily a bad thing, since E-GNSS has so far proven to be one of the best GNSS and SBAS combinations in the world. Still, in the context of the theme of our paper, it is important to mention that the new Regulation does not introduce ground-breaking changes, at least not in this segment of the Programme.

Figure 2: EGNOS segments and their cooperation with GNNSs <https://egnos-user-support.essp-sas.eu/new_egnos_ops/egnos-system/about-egnos> accessed on 10 August 2021.

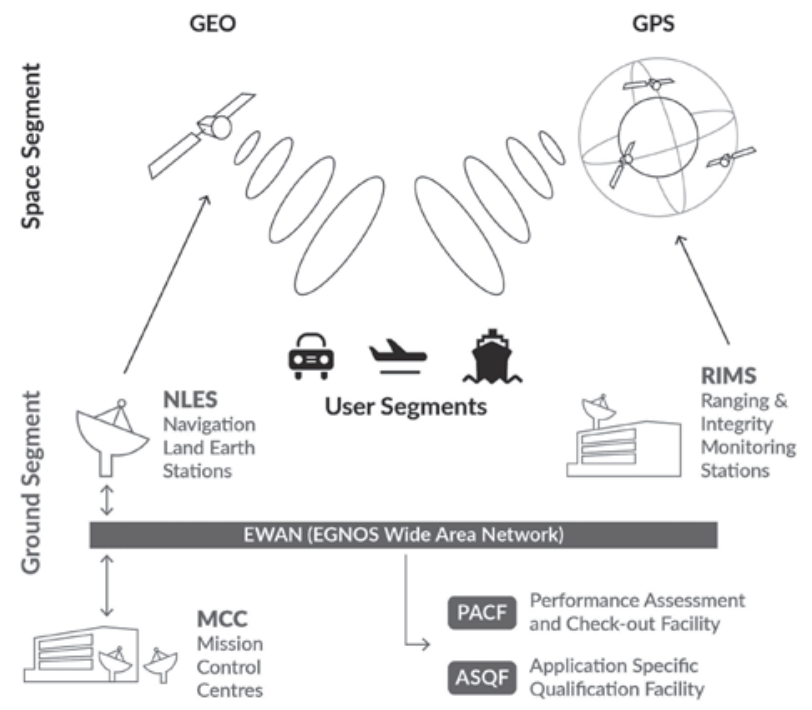

\footnotetext{
98 The EOS, or EGNOS open service, was previously referred to as OS or open service, so this change was done primarily for clarity purposes. See Regulation (EU) No 1285/2013, Art 2(5). 99 ibid, Art 2(4).

${ }^{100}$ For example, soon EGNOS v2 will be replaced by a new generation, EGNOS v3, which has been in development since the adoption of the old 2014 Regulation, when the GSA (now EUSPA) took over the management of EGNOS. See EUSPA, 'EGNOS Goes from Strength to Strength' <www.euspa.europa.eu/newsroom/news/egnos-goes-strength-strength> accessed 19 August 2021.
} 


\subsubsection{Copernicus - the European Union's Earth observation programme}

\subsection{2.a Evaluation of technical aspects}

The Regulation defines Copernicus as an

operational, autonomous, user-driven, civil Earth observation system under civil control, building on the existing national and European capacities, offering geo-information data and services, comprising satellites, ground infrastructure, data and information processing facilities, and distribution infrastructure, based on a free, full and open data policy and, where appropriate, integrating the needs and requirements of security. ${ }^{101}$

It is implemented in partnership with the Member States, ESA, EUMETSAT, the European Centre for Medium-Range Weather Forecasts (ECMWF), Mercator Océan and EU Agencies, and managed by the Commission. ${ }^{102}$ The system is served with information collected by its own satellites (the 'Sentinels', comprising six satellite families), ${ }^{103}$ but also satellites from different contributing missions, meaning existing commercial and public satellites, as well as different air, sea and ground sensors. ${ }^{104}$ Not all Sentinels are dedicated satellites - only Sentinel-1, -2, -3 and -6 are dedicated satellites, while Sentinel-4 and -5 are only instruments situated on EUMETSAT's satellites. ${ }^{105}$ ESA develops the space segment of the Copernicus programme and operates Sentinel-1, Sentinel-2 and Sentinel-5P satellites, as well as delivering the land mission from Sentinel-3. On the other hand, EUMETSAT operates the Sentinel-3 satellites and delivers the marine mission. It will do the same for the Sentinel-4 and -5 instruments, and the Sentinel-6 satellites (since this part of the Copernicus programme is not yet fully developed). ${ }^{106}$ Similarly to EGNOS, Copernicus also consists of two segments - the ground (in-situ sensors) and the space segment (the Sentinels), functioning as an interconnected whole (Figure 3). ${ }^{107}$

\footnotetext{
${ }_{101}$ EU Space Regulation, Art 3(1(c)).

102 Copernicus, 'About Copernicus' <www.copernicus.eu/en/about-copernicus> accessed 11 August 2021.

${ }^{103}$ For more, see Copernicus <https://www.copernicus.eu/en/about-copernicus/infrastructure/discover-our-satellites $>$ accessed 11 August 2021.

104 Copernicus, 'Copernicus in Detail' <www.copernicus.eu/en/about-copernicus/copernicus-detail> accessed 11 August 2021.

${ }^{105}$ Sentinel-5P, a precursor for the Sentinel-5, is, however, a dedicated satellite. See Copernicus, 'Infrastructure Overview' <www.copernicus.eu/en/about-copernicus/infrastructure-overview> accessed 11 August 2021.

106 ibid.

107 ibid.
} 
Copernicus relies heavily on international cooperation. Since the collected data are fully open and free to all users ${ }^{108}$ (which includes the reproduction, communication to the public, distribution and modification of all Copernicus data and information and their combination with other data and information), ${ }^{109}$ the EU seeks reciprocity in data exchanges for the Copernicus programme's benefit. ${ }^{110}$

The Copernicus Programme consists of the following: 1) data acquisition, which includes the development and functioning of the Sentinels, access to third-party space-based Earth observation data and to in-situ and other auxiliary data; 2) Copernicus Services, which process the collected data and information; 3) infrastructure and services for data access and distribution in a user-friendly manner; and 4) user uptake, market development and capacity building. ${ }^{111}$ Through these components, we can distinguish the six main areas covered by the Copernicus programme: atmosphere, marine, land, climate change, security and emergency (Figure 3). ${ }^{12,113}$ It is important to put more emphasis on Copernicus' role in security, because it enables better maritime surveillance, surveillance within the Union and at its external borders, and helps in achieving Common Foreign and Security Policy objectives. ${ }^{114}$ Some argue that this even opens space for a greater role of the European Union Satellite Centre (SATCEN), although this can now be brought into question. ${ }^{115}$ In this sense, SATCEN conducts the operations of the Copernicus services in Support to EU External Action, which provides geospatial information on events outside European borders that could have implications for European and global security. ${ }^{116}$ Although a common defence

\footnotetext{
108 'Copernicus shall deliver data and information building on the needs of the Copernicus users and based on a free, full and open data policy'. EU Space Regulation, Art 49(2). This freedom, however, has some limitations: the formats, timeliness and dissemination characteristics of Copernicus data and information are predetermined, licensing conditions need to be abided by, as do certain security limitations and the protection against the risk of disruption of the system, as well as the protection of reliable access to Copernicus information and data. See EU Space Regulation, Art 53(1(b)).

109 ibid, Art 53(1(a)).

${ }_{110}$ Copernicus, 'Infrastructure Overview' <www.copernicus.eu/en/about-copernicus/infrastructure-overview $\geq$ accessed 11 August 2021.

${ }^{111}$ EU Space Regulation, Art 49(4).

112 Copernicus, 'Copernicus in Detail' <www.copernicus.eu/en/about-copernicus/copernicus-detail> accessed 11 August 2021.

${ }^{113}$ For more precise activities within these areas, see EU Space Regulation, Art 50 and 51(1(a) (i)-(iv) and (b)).

114 ibid, Art 51(1(c)).

115 Jean-Pierre Darnis, 'The Future of EU Defence: A European Space, Data and Cyber Agency?' IAI Commentaries 17/21, 2. See also n 126.

${ }^{116}$ Copernicus, 'About Copernicus SEA' <https://sea.security.copernicus.eu/about-copernicus-sea/> accessed 12 August 2021.
} 
and security policy is still more a wish than reality, there is potential for this policy to be accepted to a greater extent via information gathering through satellites - but only if the number of sensors is increased, so there is no exclusivity in information collecting and analysis. ${ }^{117}$ In addition, Copernicus data support civil protection and emergency response operations, enabling better preparedness for disasters and their possible prevention. ${ }^{118}$ Copernicus proved to be effective in this area during the height of the coronavirus pandemic, when the information collected by Copernicus was used to help ease traffic congestion. ${ }^{119}$ Here, we can see a similarity with the Galileo Green Lane app developed to ensure the flow of goods between the EU's internal borders during the pandemic. ${ }^{120}$ Obviously, there are many benefits from Galileo and Copernicus cooperation, and this is precisely the reason the EU has constantly advocated for a stronger connection between these two programmes. ${ }^{121,122}$

\subsection{2.b Comparison of the old and new legal framework}

Just as we did with Galileo and EGNOS, we will now compare the Copernicus legal framework established by the new Regulation and the old Regulation (EU) No 377/2014 from 2014. More changes are immediately visible than in those concerning E-GNSS. The old Regulation states that Copernicus consists of a service component ensuring the delivery of information in the same six areas, as well as a space and in-situ component which collects and processes the data. ${ }^{123}$ Therefore, we can say that

117 Darnis (n 115) 2-3.

${ }^{118}$ EU Space Regulation, Art 51(1(b)).

119 Copernicus, 'EU Space and the Coronavirus' <www.copernicus.eu/en/coronavirus> accessed 12 August 2021.

${ }^{120}$ For more, see Galileo Green Lane <https://galileogreenlane.eu/about.php> accessed 12 August 2021.

${ }^{121}$ For example, in May 2017, a Copernicus Training and Information Session was hosted by the European GNSS Agency (GSA), where it was decided that a stronger synergy between E-GNSS and Copernicus is needed. For more, see EUSPA <www.gsc-europa.eu/ news/galileo-copernicus-synergies-explored-at-prague-copernicus-forum-2> accessed 12 August 2021.

${ }^{122}$ Contrary to the situation regarding Galileo and EGNOS, the UK will most likely continue to participate in the Copernicus programme as a third country for the period 2021-2027, but will first need to assess potential exclusions applied to third-country participants. The UK will, however, remain a member of ESA and will therefore continue to participate in the space segment of the Copernicus programme (CSC-4) through the Agency (since the Agency is primarily responsible for this segment). In addition, since Copernicus has a free and open data policy, the majority of these data and services would be freely available to UK users. On the other hand, it is anticipated that the UK will not have access to data evaluated as sensitive in the security aspect. See GOV.UK <www.gov.uk/guidance/uk-involvement-inthe-eu-space-programme> accessed 12 August 2021.

${ }^{123}$ Regulation (EU) No 377/2014 of the European Parliament and of the Council of 3 April 2014 establishing the Copernicus Programme and repealing Regulation (EU) No 911/2010 
the old Regulation contained only the first two elements of which Copernicus consists. In contrast to the new Regulation, infrastructure and services for data access and distribution in a user-friendly manner, user uptake, market development and capacity building were missing. Due to the nature of these elements, it is hard to believe that no activities which could fall into these categories had not been taken even before the new Regulation. The fact that they are now explicitly mentioned in the new Regulation is a consequence of the contemporary tendency to adopt a user-friendly, closer approach in many services provided by public authorities, which is certainly a positive thing. However, their legal introduction is far from being just a proclamation driven by modern tendencies: since these elements are now an integral part of the legal framework, there is an obligation for these proclamations actually to be fulfilled. Whether this actually happens or not remains to be seen. In the vocabulary of human rights law, positive obligations always present a greater challenge than negative ones, especially when they are the result of new developments, such as this one. Still, this framework at least provides solace for future Union activities regarding Copernicus.

Other segments of the legal framework are basically the same - for example, provisions concerning the Copernicus data policy use almost identical formulations. ${ }^{124}$ There is a small difference, looking quickly from the linguistic perspective, concerning the security aspect of the Copernicus Programme. The new Regulation explicitly states that the goal here is to support the Common Foreign and Security Policy objectives and actions, while the old Regulation in this context mentions only agreements which can be concluded between the Commission and Common Foreign and Security Policy bodies. ${ }^{125}$ It can be argued that the new formulation places greater emphasis on the Common Foreign and Security Policy, and in this way tries firstly to further promote it, and, secondly, to boost the role of Copernicus (as well as that of all space-related activities) in the Policy itself. ${ }^{126}$ Still, a common policy in the defence and security area is far from reality, despite the Union's efforts. This could be one of the motivating factors.

Text with EEA relevance [2014] OJ L122, Art 2.

124 Compare the EU Space Regulation, Art 53(1) and Regulation (EU) No 377/2014, Art 23.

125 Compare EU Space Regulation, Art 51(1(c)) and Regulation (EU) No 377/2014, Art 5(1(f)).

126 On the other hand, the new Regulation does not mention the SatCen in this context, whereas the previous one does. It only mentions it when talking about other entities which can also be involved in the Programme. This can be seen as something which the EU did in order to place less importance on the institution, and its transition to other bodies, such as the newly established EUSPA. See EU Space Regulation, Art 51(1(c)) and Regulation (EU) No 377/2014, Art 5(1(f)). 

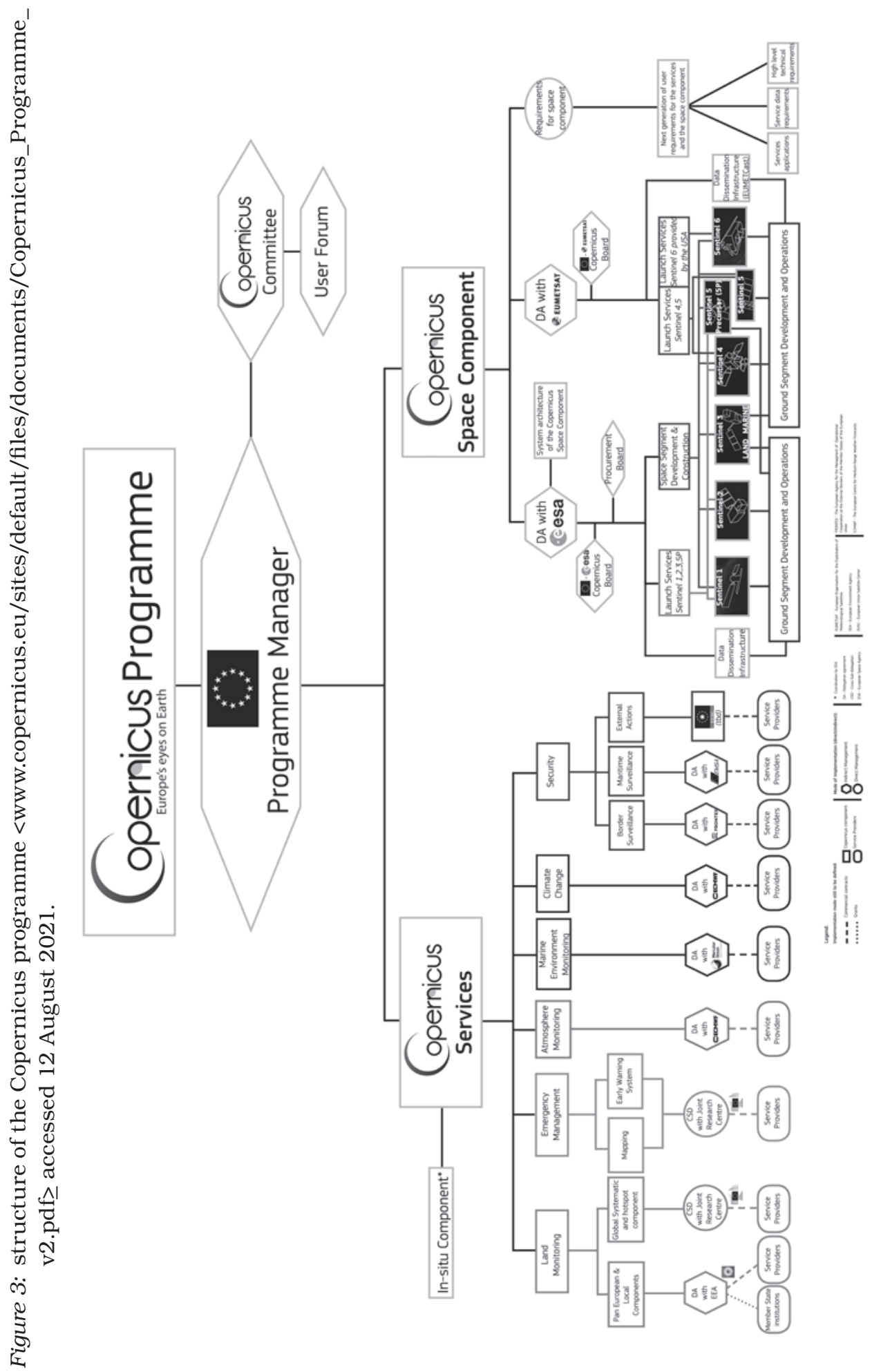


\subsubsection{Space Situational Awareness}

\subsection{3.a Evaluation of technical aspects}

Space Situational Awareness (SSA), as a component of the EU Space Programme, consists of three sub-components (Figure 4): the Space Surveillance and Tracking (SST) sub-component; the Space Weather (SWE) sub-component; and the Near Earth Object (NEO) sub-component. ${ }^{127}$

According to the Regulation, the SST sub-component is a 'space surveillance and tracking system aiming to improve, operate and provide data, information and services related to the surveillance and tracking of space objects that orbit the Earth'. ${ }^{128}$ Its main purpose is to create a network of ground and space-based SST sensors for surveying and tracking space objects, as well as the creation of a European catalogue of space objects, including the analysis of data collected through these sensors. ${ }^{129}$ It also provides SST services, as well as activities concerning the development of different solutions for safe and efficient spacecraft disposal at the end of the operational lifetime, reducing and eliminating space debris, and space traffic management. ${ }^{130}$

Next to the development and functioning of SST sensors, the most important segment of this sub-component is SST services, since the sensors' ultimate goal is nothing other than to provide precisely these. The services include the risk assessment of potential collisions between spacecrafts or between spacecrafts and space debris, the uncontrolled re-entry of space objects and debris into the Earth's atmosphere, including the generation of collision avoidance alerts and the estimated timeframe and location of the possible impact of re-entered objects and debris, respectively, and detecting and providing descriptions of in-orbit fragmentations, collisions, and break-ups. In addition, special attention is given to space debris, or, more precisely, its mitigation and remediation. ${ }^{131}$ In the context of the EU, the importance of these services can be seen in the recent example of Copernicus Sentinel-2A, which had to perform a collision avoidance manoeuvre on 27 June 2021, which resulted in some services not being available as normal, and this is becoming an ever more frequent problem. ${ }^{132}$ All of these SST services are free of charge and are always available without interruption. ${ }^{133}$

\footnotetext{
${ }^{127}$ EU Space Regulation, Art 3(1(d)).

128 ibid, Art 3(1(d) (i)).

129 ibid, Art 54(1(a) and (b)).

130 ibid, Art 54(1(c) and (d)).

131 ibid, Art 55(1).

${ }^{132}$ See <https://scihub.copernicus.eu/news/News00904> accessed 13 August 2021.

${ }^{133}$ EU Space Regulation, Art 55(2).
} 
The Regulation differentiates Union and international SST users. Union users are, of course, in a better position, but the Regulation divides this category in two subcategories - core and non-core users, with different capabilities. SST core users are: Member States, the European External Action Service (EEAS, the EU's diplomatic service), the Council, the Commission, EUSPA, and public and private spacecraft owners and operators established in the Union; non-core users are defined by a general clause - these are all other public and private entities established in the Union. ${ }^{134}$ Core users have access to all SST services, while non-core users do not have access to the risk assessment of potential collisions between spacecrafts or between spacecrafts and space debris, and the generation of collision avoidance alerts. ${ }^{135}$ On the other hand, international SST users are: third countries, international organisations which do not have headquarters in the EU, and private entities established outside the EU - they have access only to services related to debris mitigation and remediation, and only if they conclude an adequate agreement (this agreement is concluded between the EU and a third country or an international organisation, or the EU and the third country in which a private entity is established, if the subject is a private entity established outside the EU). ${ }^{136}$ This agreement is, however, not necessary for access to all other publicly available SST services. ${ }^{137}$ In this sense, the position of international users is not that bad. ${ }^{138,139}$

The SWE sub-component is concerned with observational parameters related to space weather events. ${ }^{140}$ The Regulation does not provide much detail on this sub-component, since it delegates authority for determining SWE services to the Commission. It does, however, emphasise that SWE services need to be provided at the Union level according to the needs of SWE users, technological readiness, and after a risk assessment. ${ }^{141}$ Public or private entities which will provide these services will be chosen through a procurement procedure. ${ }^{142}$

\footnotetext{
134 ibid, Art 56(1).

135 ibid, Art 56(1).

136 ibid, Art 56(2).

137 ibid, Art 56(2).

${ }^{138}$ Even Member States, as core SST users, need to fulfil certain, not so easy to accomplish, criteria. See ibid, Art 57.

139 The UK is now considered as a third country, and although UK users can still receive SST services, they cannot participate in the programme itself. See GOV.UK <www.gov.uk/ guidance/uk-involvement-in-the-eu-space-programme> accessed 13 August 2021.

140 ibid, Art 3(1(d)(ii)).

${ }^{141}$ ibid, Art 60(2).

142 ibid, Art 60(3).
} 
Finally, the NEO sub-component deals with the risk monitoring of near-Earth objects approaching the Earth. ${ }^{143}$ It supports the mapping of Member States' capacities for the detection and monitoring of near-Earth objects, the characterisation of newly discovered objects of this kind, and the creation of a European catalogue of these objects. ${ }^{144}$ If Earth finds itself in a situation where action needs to be taken to destroy an approaching near-Earth object, or alter its course, or minimise potential damage to Earth, then the Commission has the authority to coordinate such action, which will be taken in cooperation with relevant UN bodies. ${ }^{145}$ It is certainly commendable that the EU has taken legislative action to regulate even this aspect of potential space-related harmful events, since so far these events have been regarded as something from sci-fi novels.

\subsection{3.b Comparison of the old and new legal framework}

Concerning the comparison of the old and the new legal framework, there is an even greater difference than that of Copernicus. Not only has the framework changed (or, better, expanded), but so has the legal instrument - this segment of the Programme was regulated by a Decision, ${ }^{146}$ not a Regulation. As we all know, Decisions are binding only on those they are directed to, whereas Regulations are binding acts which need to be applied in their entirety in the whole EU. This change automatically places greater importance on this area of the EU's space activities. What is more important, however, is that the old Decision regulated only what is now just a sub-component of the SSA component, and that is the SST sub-component (which the new Regulation copies to a great extent). ${ }^{147}$ The SWE and NEO sub-components are introduced by the new Regulation, and together with the old SST they form the SSA. This can also explain the fact that these two sub-components are much more superficially regulated, by only two short articles. ${ }^{148}$ As was implied while discussing the NEO sub-component, this is a significant step forward in the right direction, which shows that the EU is aware of future developments in space-related activities.

\footnotetext{
143 ibid, Art 3(1(d)(iii)).

144 ibid, Art 61(1).

145 ibid, Art 61(2).

${ }^{146}$ Decision No 541/2014/EU of the European Parliament and of the Council of 16 April 2014 establishing a Framework for Space Surveillance and Tracking Support [2014] OJ L158.

${ }_{147}$ There is a difference concerning the SatCen. The old Decision stated that the SatCen may cooperate with the consortium regarding SST activities, but the new Regulation mentions the SatCen in this context only in the Preamble, where it refers to this Decision, which is now no longer in force. Of course, the Regulation does state that SATCEN can be involved in the Programme's activities, but it groups it with other entities. See Decision No 541/2014/EU, Art 8 and EU Space Regulation, Preamble, para 49 and Art 32.
}

${ }^{148}$ EU Space Regulation, Arts 60 and 61. 
Figure 4: structure of the SSA component <https://swe.ssa.esa.int/DOCS/ SWWT/m31/SSA_SWE_achievements.pdf> accessed 24 August 2021.

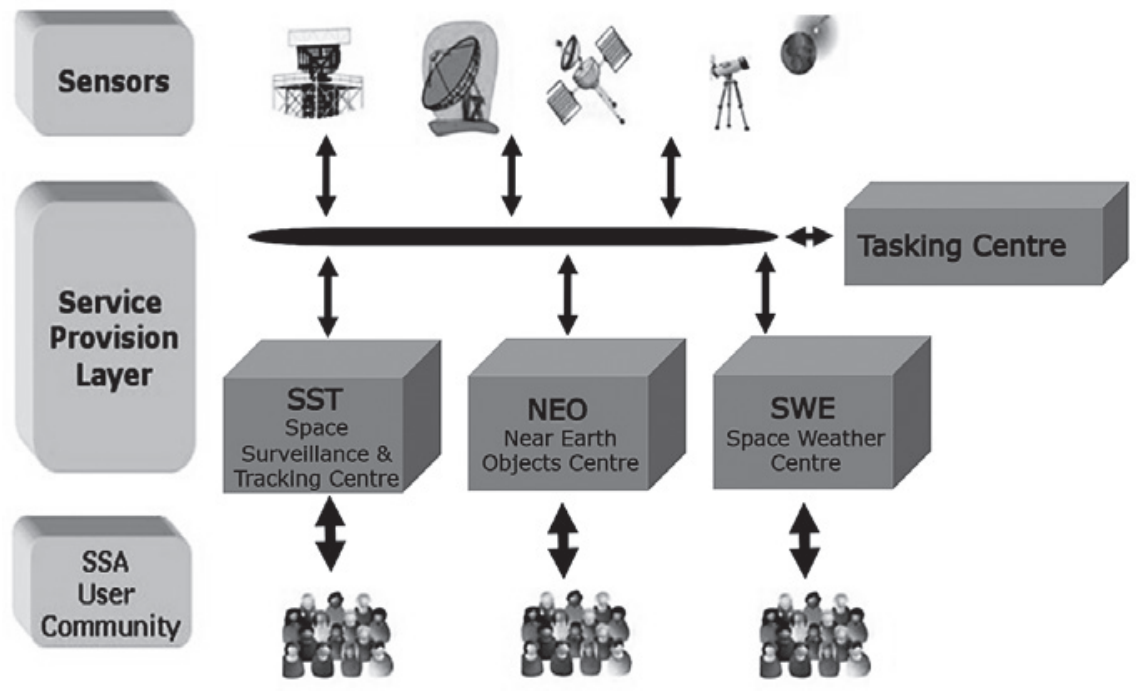

\subsubsection{European Union Governmental Satellite Communications}

\subsection{4.a Evaluation of technical aspects}

Governmental Satellite Communications (GOVSATCOM) is a 'satellite communications service under civil and governmental control enabling the provision of satellite communications capacities and services to Union and Member State authorities managing security critical missions and infrastructures.. ${ }^{149}$ The question that automatically arises is why there is even a need for such a special service with its separate capacities, since normal satellite communication should already be encrypted to a significant extent. The answer lies in the fact that potential man-made or natural disasters could restrict or endanger secure communication between Member States' governments. ${ }^{150}$ By creating a special infrastructure, which would, in addition to being available during even the most critical events, be more secure and resilient to different types of cyberattacks, the aforementioned potential dangers could be avoided. Obviously, this is connected to a great degree to the defence and security of the Union, so the European Defence Agency (EDA) played an important role in the formation of this part of the Programme. ${ }^{151}$

\footnotetext{
149 ibid, Art 3(1(e)).

150 EUSPA, GOVSATCOM <www.euspa.europa.eu/european-space/govsatcom> accessed 13 August 2021.

${ }^{151}$ EDA, GOVSATCOM <https://eda.europa.eu/what-we-do/all-activities/activities-search/ governmental-satellite-communications-(govsatcom)> accessed 13 August 2021.
} 
Although GOVSATCOM was already recognised as one of the most important goals of the Union's activity in space- and defence-related activities in the Commission's Space Strategy for Europe and the European Defence Action Plan, adopted in 2016, ${ }^{152}$ real action was taken only in 2019, when the European Parliament initiated the GOVSATCOM Preparatory Action, and then in 2021, when it officially became a part of the EU Space Programme with the new Regulation. ${ }^{153}$

This part of the new Programme is still in its very early phases compared to the previously mentioned components, especially Galileo, which is the oldest. Therefore, the Regulation contains provisions which deal with the sharing and prioritisation of GOVSATCOM capacities, services and user equipment. An analysis needs to be made of the safety and security risks of users, which takes into consideration the existing communication infrastructure, and the availability and geographical coverage of existing capabilities, so that this sharing and prioritisation can be done in accordance with the relevance and importance of GOVSATCOM users. All of this is placed in the hands of the Commission. ${ }^{154}$

The Regulation differentiates four types of subjects which play a role in this component of the Programme: GOVSATCOM users, participants, providers, and authorities. GOVSATCOM users are Union or Member State public authorities or bodies entrusted with the exercise of such public authority, as well as natural or legal persons acting on behalf of and under the control of the previously mentioned entities, but only provided that they are entrusted with the management and supervision of emergency and security-critical missions, operations and infrastructures. ${ }^{155}$ Member States, the Council, the Commission, and the EEAS are all considered as GOVSATCOM participants if they authorise GOVSATCOM users, provide satellite communication capacities, ground segment sites, or part of the ground segment facilities. ${ }^{156} \mathrm{EU}$ agencies, third countries and international organisations can also become participants, but only under specific conditions. ${ }^{157}$ Interestingly, the Regulation specifically states that the exercise of these actions does not contravene the neutrality or non-alignment provisions contained in the constitutional laws of the Member States. ${ }^{158}$ This is obviously a measure which tries to

\footnotetext{
152 ibid.

153 EUSPA, GOVSATCOM <www.euspa.europa.eu/european-space/govsatcom> accessed 13 August 2021.

154 EU Space Regulation, Art 66.

155 ibid, Art 65.

156 ibid, Art 68(1).

157 ibid, Art 68(2-3).

158 ibid, Art 68(1). For the question of neutrality and participation in a common defence and security policy and potential problems arising from this, see Clara Sophie Cramer and U1-
} 
shift the opinion of certain Member States, which are still not entirely sold on the idea of a common defence and security policy, and move them towards stronger cooperation in this area. Every GOVSATCOM participant needs to designate a competent GOVSATCOM authority which would act mostly as a supervisory body. ${ }^{159}$ Finally, providers of satellite communication capacities and services include GOVSATCOM participants, as well as duly accredited legal persons. ${ }^{160}$

\subsection{4.b Comparison of the old and new legal framework}

Since GOVSATCOM is a very recent development, we cannot compare the legal framework established by the new Regulation with the previous one, as we did for all the previous segments of the Space Programme. The same stands for this segment's future. It is still too early to reach any firm conclusions. It is certainly a welcome change, but whether or not it will actually meet expectations depends on many factors which cannot be predicted at this point.

\section{Space-related activities in Member States: the example of Croatia}

The space industry has a major impact on the development of national economies, which is expected to increase significantly in the future. The interest of countries in the development of the space economy is vital for them, especially for the development of high technology and research. The space industry consists of the design, development, and production of: (a) launch systems; (b) spacecraft; and (c) earth-based equipment for public and private use. This industry includes components and systems for aircraft, satellites, and ground stations, microwave devices, robotics, and software tools for system design and control. It contributes to smart and sustainable economic growth, promotes scientific progress, and increases the number of high value-added jobs in communications, navigation, and Earth observation. The commercialisation of space provides Europe with independence and security, while the space industry contributes to solving problems in the fields of climate, energy, environmental protection and healthy food. This is especially important for smaller countries which can, if they have the human resources, establish themselves as valuable participants in this sector, while at the same time fostering their economic growth. For this reason, we will take a look at Croatia which we believe is a good example of such a country.

rike Franke (eds), Ambiguous Alliance: Neutrality, Opt-outs, and European Defence (European Council on Foreign Relations, 28 June 2021) available at <https://ecfr.eu/publication/ ambiguous-alliance-neutrality-opt-outs-and-european-defence/> accessed 14 August 2021.

${ }^{159}$ EU Space Regulative, Art 68(4-5).

160 ibid, Art 64. 
First of all, Croatia's commitment to the development of science, technology, and economic activities related to space is inevitable. One of the prerequisites for this engagement is the membership of the Republic of Croatia in ESA, as well as contacts with other national space agencies. EU membership is of course also a significant factor, but so far Croatian companies have not been very successful in securing funds from specialised space-related budgets. When they are secured, it is mostly from other segments of the EU budget, such as the European Regional Development Fund. ${ }^{161}$ The other significant way of financing is through ESA tenders. This is why we will focus on ESA, since so far more activities in this area have been conducted with ESA than with the EU, but also because ESA is still the EU's greatest collaborator. Consultations between ESA and Croatia, represented by the Ministry of Science and Education, on their possible cooperation started in 2014, with the first meeting taking place in Zagreb in May 2015. In February 2018, Croatia signed a Cooperation Agreement, ${ }^{162}$ which marked the first phase of Croatia's rapprochement and admission to ESA. Following the Cooperation Agreement, a country can obtain the status of European Cooperating State (ECS) and then become a full member of ESA in the third phase. An ECS country gains access to the Plan for European Cooperating States (PECS) and becomes a participant in PECS cooperation. ${ }^{163}$ Each of the two phases preceding full membership of ESA lasts five years, with the possibility of this period being extended.

In its current status, Croatia can participate as observer in ESA Council meetings and in its subordinate bodies, exchange information with ESA through workshops, training programmes and the usage of specific data. It can also use ESA assistance in compiling a national space strategy. Areas of cooperation include: 1) space science, in particular astronomy and astrophysics, solar system research and solar earth physics; 2) research and the application of Earth observation, in particular environmental monitoring, meteorology, aeronomy and geoinformatics and disaster management; 3) telecommunications, including service demonstrations, as well as satellite navigation; 4) research into microgravity, in particular space biology and medicine, and materials processing; 5) technology development, including software and computer hardware support; and 6) engineering and use of ground infrastructure. The collaboration also extends to: 1) the award of scholarships; 2) exchange of experts to participate in studies; 3) joint conferences and symposia; 4)

\footnotetext{
${ }^{161}$ Geolux <www.geolux-radars.com/esif.html> accessed 4 September 2021.

${ }^{162}$ ESA, 'Croatia Signs Cooperation Agreement' <www.esa.int/About_Us/Corporate_news/ Croatia_signs_Cooperation_Agreement> accessed 2 September 2021.

${ }^{163}$ ESA, 'Plan for European Cooperating States' <www.esa.int/About_Us/Plan_for_European_Cooperating_States $>$ accessed 2 September 2021.
} 
joint promotion of the use of the products and services developed; 5) promoting educational activities in space science and technology; and 6) providing expertise and assistance in the management of space projects. ${ }^{164}$

By signing the Cooperation Agreement, Croatia may participate, but only as an observer, in the meetings of the PECS Committee. The Ministry has already started discussions with ESA on participation in activities under the PECS programme. One of the issues in the negotiations is the amount of annual contribution to be paid by the State for the implementation of joint programmes with ESA during participation in PECS. The minimum annual contribution is EUR 1 million, which would go exclusively to Croatian companies or institutions through ESA tenders. These companies could become one of the carriers of the future high-tech economy that Croatia is aiming for. The Croatian institutions involved in space are the Ruđer Bošković Institute (RBI), the Meteorological and Hydrological Service (DHMZ), the National Protection and Rescue Directorate (DUZS), the Croatian Academy of Science and Arts (HAZU), and the Faculties of Science, Electrical Engineering and Computing, Geodesy, Transport, Mechanical Engineering and Naval Architecture of the University of Zagreb, as well as other leading universities. In Croatia, a small number of companies are commercially active in the space and satellite industry, with the leading ones being Amphinicy, ${ }^{165}$ Atos, ${ }^{166}$ Geolux, ${ }^{167}$ Hipersfera ${ }^{168}$ and Orqa. ${ }^{169}$ Croatian companies active in space are particularly successful in the development of satellite software. What is of utmost importance for Croatia currently is to obtain the status of an ECS country, the next step in its cooperation with ESA, as it will then be able to participate in ESA project tenders. ${ }^{170}$ In addition, by becoming an ECS member of ESA, Croatian nationals will be allowed to apply for time-limited positions to work at ESA - namely, internships available while studying and co-funded space-related $\mathrm{PhD}$ and post-doc research activities. Such programmes would greatly increase interest in space research and contribute to structuring, retaining and sharing of space-related technology, knowledge and research.

\footnotetext{
164 Zakon o potvrđivanju Sporazuma između Vlade Republike Hrvatske i Europske svemirske agencije o svemirskoj suradnji u mirnodopske svrhe (NN 5/2018).

$165<w w w . a m p h i n i c y . c o m>$ accessed on 2 September 2021.

$166<$ https://atos.net/hr/hrvatska> accessed 2 September 2021.

$167<$ www.geolux-radars.com> accessed 2 September 2021.

$168<$ https://hipersfera.hr> accessed 2021.

$169<$ https://orqafpv.com/about> accessed 2 September 2021.

170 Companies and entities must register for tendering on the esa-star system, in order to do business with ESA, such as responding to an open invitation to tender. A list of registered entities can be found at <https://esastar-emr.sso.esa.int/PublicEntityDir/PublicEntityDirSme> accessed 2 September 2021.
} 
The space programme and related research and development activities are among the fastest growing fields in the world, and no slowdown is expected in the near future. The commercialisation of space at a global scale is still in the early stages of development and Croatia has the opportunity to join this project as an active participant, and this opportunity should not be missed. This requires first and foremost a strategic commitment towards the development of the space sector through investments in education, research, the high technology industry and activities in the field of space medicine and space law. This is based on education focused on creativity and openness to new ideas, skilled and well-trained professionals, high-quality basic and applied research and innovation, and the development of new devices, systems and solutions for use in space applications. The space sector includes a large number of different activities that will not deliver satisfactory results without unified coordination. For Croatia, as a small and medium-developed country, there are two possible directions of development. One is to encourage the development of companies without special coordination, which would supply components for large space projects of other countries or agencies under subcontracts. The advantage of such an approach is that the government has no responsibility for organising the complex space sector, while the disadvantage is that narrowly specialised companies are sensitive to market competition. Another vision is to organise the space sector so that scientific and technological activities are clustered around a common programme. The advantage of an organised and joint programme is that such a programme ensures greater economic stability, while its disadvantage is that it would be difficult to launch without the involvement of the state and without effective coordination, which the state could provide, of all the components of the sector.

The Adriatic Aerospace Association (A3), ${ }^{171}$ established in Croatia together with the Association of Small and Medium Space Companies (SME4SPACE), proposes that the first step at the state level should be the adoption of a document expressing the position of the Republic of Croatia in international space activities based on its human, scientific and technological capabilities, geographical environment and membership in the EU. A3 is a non-governmental, non-profit and independent association established with the aim of promoting aerospace research and development, education, consultancy, and international cooperation. The founding members are private and public entities from the scientific and technological sector with the basic intention of promoting the stated goals.

\footnotetext{
171 Adriatic Aerospace Association: Programme A3 <https://a3space.org/?page_id=3621\&
} lang=hr $>$ accessed 2 September 2021. 
The current situation offers good prospects for increasing Croatia's share of the global space market. Due to their complexity and high costs, long-term scientific research programmes as well as individual space projects must have stable and sustainable political support and be financially supported by the state. This would enable the creation of specialised institutions for the preparation and implementation of space projects in Croatia, which would then strengthen the space industry and establish cooperation with scientific institutions. The space industry is a multidisciplinary field with a wide range of scientific and technological challenges. It connects scientists with the economy, opens room for innovation, and motivates young scientists and engineers to start new businesses focused on the technological challenges related to the conquest of space. Investments in the space sector and the development of the space industry, with a focus on small and medium-sized enterprises, will create high-quality jobs and increase the added value of space technologies for the non-space sector.

Croatia does not have a developed space programme, although it has the potential to form one through simpler projects. Rapid development is possible in some areas: in the construction of small satellites, in the production of components and subsystems for space transportation systems, in the implementation of robotics and sensor technology, in SAR (Synthetic Aperture Radar) technology, in the study of weather and climate change, in maritime surveillance, in the processing of Earth observation data, and in the development and production of materials and structures resistant to temperature, magnetic fields and cosmic radiation.

As one of the steps in the development of space technologies in Croatia, initiatives for the construction of nanosatellites have already been launched. One of these projects is the construction of the FERSAT satellite at the University of Zagreb, Faculty of Electrical Engineering and Computing. ${ }^{172}$ The FERSAT satellite is planned in the $1 \mathrm{U}$ CubeSat format, with a volume of one litre and a weight of no more than $4 / 3$ kilograms. It will measure light pollution (which is night-time light radiated from the Earth into space) and the ozone layer (as the reflected sunlight during daytime) and transmit back the recorded data. The expected contributions of this project are: 1) education of students in space and communication technologies and the increase of interest in space technologies in Croatia; 2) cooperation with small and medium enterprises in the development of space technologies; 3) scientific research and professional work in the field of space technologies; and 4) the collection of information about Croatia from space that will be useful for organisations deal${ }_{172}$ Faculty of Electrical Engineering and Computing, 'FERSAT: Description of the Project
<www.fer.unizg.hr/zkist/FERSAT/projekt> accessed 2 September 2021 . 
ing with the environment, weather, climate change and energy efficiency. The first phase of the project was supported by the Croatian Science Foundation through the project CROSPERITY - Platform for Satellite Measurement of Electromagnetic Radiation. ${ }^{173}$ FERSAT has the potential to inspire students to increase their engagement in the space sector and strengthen their competences in science, technology, and engineering.

The construction of a Croatian nanosatellite is also planned within the Adriatic Aerospace Association (A3) project, which aims to manufacture and launch the first Croatian satellite based on the $2 \mathrm{U}$ CubeSat format. ${ }^{174}$ The main idea of the A3 project is to produce the satellite entirely in Croatia. This should be the work of Croatian experts from various companies and not a product consisting of parts bought abroad or a finished foreign satellite. The satellite would contain a camera, a communication system, computer support, parts of the ground station and communication software that would be developed in Croatia, which would allow the participation of Croatian companies and experts in the development of new, sophisticated technologies. The satellite will be named Perun, after the Slavic god of thunder and lightning. The Perun project will be carried out by a large number of young engineers and scientists. They will be guided by experienced staff at universities and scientific institutions through project reviews and support. These engineers and scientists will not only learn the theory of space technology, but also gain a variety of practical experience. Students who acquire knowledge in space engineering often apply it to other high technologies - biomedical engineering, mechanical engineering, software engineering, etc.

Croatia's focus on the development of the space sector is also evident in the Decision on Measures to Strengthen National Participation in European Union Programmes in the Field of Research, Innovation and Space, adopted by the Ministry of Science and Education in 2021. ${ }^{175}$ The Decision aims to improve the quality and number of applications for tenders under the Programmes, increase the scientific excellence of applicants, strengthen the human and operational capacities of project offices and other organisational units in Croatian science organisations, and promote participation in research and innovation initiatives related to space and space technologies. Financial support from the Ministry of

\footnotetext{
173 Faculty of Electrical Engineering and Computing, 'FERSAT: Crosperity' <www.fer.unizg. hr/zkist/FERSAT/crosperity> accessed 2 September 2021.

174 Perun <https://perun-i.hr/> accessed 2 September 2021.

175 Ministry of Science and Education, Decision on Measures to Strengthen National Participation in European Union Programmes in the Field of Research, Innovation and Space <www.obzoreuropa.hr/userfiles /files/Odluka\%20o\%20mjerama\%20za\%20jačanje $\% 20$ nacionalnog\%20sudjelovanja\%20u\%20programima\%20Europske\%20unije \%20u\%20području\%20istraživanja\%2C\%20inovacija\%20i\%20svemira.pdf> accessed 2 September 2021.
} 
Science and Education is provided for international competitive projects funded under the Horizon Europe Framework Programme for Research and Innovation, the EURATOM Research and Training Programme for the period 2021-2025, the European Institute of Innovation and Technology Programme, the European Union Space Programme, and European Space Agency tenders. ${ }^{176}$

Taking into account all these activities, Croatia has the opportunity to promote the development of the space industry, facilitate cooperation between the private and public sectors, academic institutions and scientific institutes, enable the integration of the space sector with other sectors, including energy, health, tourism, climate change, information and communication technology, and the development of collaboration that will lead to innovative space-based solutions for social and economic growth. Therefore, Croatia should define a National Space Strategy and a National Space Programme. Cooperation in space-oriented technologies between science, industry, and the economy must be established as a strategic goal at the state level. According to the UN 'Space2030' agenda, ${ }^{177}$ the strategic goals of the development of space-related capabilities and technologies are: 1) space economy, which leads to space-derived economic progress; 2) space society, which leads to progress in social activities related to space; 3 ) accessibility to space, which means access to space for all; 4) space diplomacy, which strengthens partnerships and international cooperation in the management of space activities. Similar strategic goals should be set in Croatia for the exploration, understanding, and use of space. Without cooperation and partnership between the private and public sectors, academic institutions, and research centres in the field of space utilisation, these goals will not be achieved.

\section{Some questions still remain}

Although the Regulation does establish a legal framework for many aspects of the new Space Policy, a few questions are left unanswered. The Regulation falls short in terms of the liability of the Union and/or Member States, as well as its partners in the Programme, for potential damages caused by different segments of its Space Programme. Connected to this, the type of approach used by the Union in creating an EU Space Programme and Space Policy is still debatable - is this really

\footnotetext{
176 Ministry of Science and Education, Decision on Measures to Strengthen National Participation in European Union Programmes in the Field of Research, Innovation and Space, Press Release <www.obzoreuropa.hr/novosti-pregled/mzo-odluka-mjere-za-jacanje-nacionalnog-sudjelovanja-u-programima-europske-unije> accessed 2 September 2021.

177 Consolidated draft 'Space2030' Agenda and Implementation Plan <www.unoosa.org/ oosa/en/oosadoc/data/documents/2021/aac.1051/aac.1051.321_0.html> accessed 2 September 2021.
} 
an approach which will ensure the inclusion of all Member States in space-related activities, or will it deepen the differences between them? In addition, the Regulation does not cover all environmental aspects of the Programme, for example the impact of satellites and their reflectory external coatings on astronomical activities. Therefore, in the next few subsections, we will take a look at these potential problems and their impact on the Union's continuing efforts in space-related activities.

\subsection{Liability - are provisions of international law enough?}

Concerning liability, the Regulation explicitly mentions it when establishing the legal framework for the European Union Space Agency. ${ }^{178}$ Although the Agency does play a significant role in the operational aspect of the EU Space Programme, it is certainly not the only participant in the Programme, and besides does not necessarily even participate in some parts of the Programme. ${ }^{179}$ Therefore, we need to take a look at liability in a broader sense - liability for the whole Space Programme, not only the liability of only one body, and only for a part of the Programme. Of course, as stated before numerous times, the EU insists on its cooperation with other countries, international organisations and private sector subjects outside the EU in its space-related activities, and the signing of different agreements and contracts is a prerequisite for successful cooperation, where provisions concerning liability will usually be included in those contracts. Still, many contracts only point to the relevant provisions of international law, or simply ignore this problem. In addition, there is always the possibility of a situation arising not regulated by any agreement at all, or those in which the Union acts as a sole subject. All these examples show that there is a clear need for the regulation of this question.

Before we consider the possible ways of resolving this question at the EU level, we need to examine international law governing the liability of different subjects in regard to damages caused by space objects.

\footnotetext{
${ }^{178}$ Regarding the Agency's contractual liability, it is governed by the law applicable to the contract in question, with the Court of Justice of the European Union having jurisdiction to give judgment pursuant to any arbitration clause present in an Agency-signed contract. Regarding non-contractual liability, the Agency will repair any damage caused by its departments or its servants, according to the general principles of law common to Member States, with once again the Court of Justice having jurisdiction in disputes over compensation for the aforementioned damages. See ibid, Art 97.

179 The Agency does play an important role in regard to Galileo, EGNOS and Copernicus (operational management of Galileo and EGNOS, developing applications based on data provided by Galileo, EGNOS and Copernicus), to some degree in GOVSATCOM also (coordination of user-related aspects of this segment of the Programme), but does not participate in the SSA segment of the Programme unless the Commission entrusts the Agency with tasks related to this segment. See EUSPA, 'What We Do' <www.euspa.europa.eu/about/ what-we-do> accessed 15 August 2021.
} 
The Convention on International Liability for Damage Caused by Space Objects, ${ }^{180}$ being the main document establishing the rules in this segment of international space law, firstly defines some basic terms. For our purposes, these four are the most important: damage means 'loss of life, personal injury or other impairment of health; or loss of or damage to property of States or of persons, natural or juridical, or property of international intergovernmental organizations'; launching State is defined as a 'State which launches or procures the launching of a space object' but also as a 'State from whose territory or facility a space object is launched'; and a space object ${ }^{181}$ 'includes component parts of a space object as well as its launch vehicle and parts thereof', while launching also includes attempted launches. ${ }^{182}$ Article 2 establishes the principle of strict liability for damage caused on the surface of the Earth or to aircraft flight, while Article 3 establishes the principle of fault-based liability for damage caused elsewhere than on the surface of the Earth. ${ }^{183}$ What is important in the context of the EU is regulated by Articles 4 and 5, which regulate the cases of joint and several liability - the aforementioned main principles are still applied, but in cases of joint launchings, then the launching States are usually proportionally responsible. However, there are two other options: in cases in which the extent of the fault of each of the States cannot be established, then: 1) the burden of compensation can be apportioned equally between them; 2) or they can conclude agreements regarding the apportioning of financial obligations. ${ }^{184}$ Why is this important in the context of the EU? In order to answer this, another explanation needs to be given first.

Article 6 of the Outer Space Treaty (the main treaty regulating international space law) explicitly states that the national states are primarily responsible for the actions of governmental agencies and non-governmental entities with regard to activities in space. ${ }^{185}$ This opens the question of the EU's responsibility for its Space Programme, since the EU's nature is still, at least in legal theory, discussed in international and constitutional

\footnotetext{
${ }_{180}$ Resolution adopted by the General Assembly 2777 (XXVI), Convention on International Liability for Damage Caused by Space Objects, Art 1 <www.unoosa.org/oosa/en/ourwork/ spacelaw/treaties/liability-convention.html> accessed 15 August 2021.

${ }^{181}$ A space object is also defined by the EU Space Regulation, as 'any man-made object in outer space'. See EU Space Regulation, Art 2(2).

${ }_{182}$ Resolution adopted by the General Assembly 2777 (XXVI), Convention on International Liability for Damage Caused by Space Objects, Art 1 <www.unoosa.org/oosa/en/ourwork/ spacelaw/treaties/liability-convention.html> accessed 15 August 2021.

183 ibid, Arts 2-3.

184 ibid, Art 4-5.

185 Treaty on Principles Governing the Activities of States in the Exploration and Use of Outer Space, including the Moon and Other Celestial Bodies (Outer Space Treaty), Art $6<w w w$. unoosa.org/pdf/gares/ARES_21_2222E.pdf> accessed 25 August 2021.
} 
law. Hollis discusses the position of the EU in the typology of these nonstate actors (although the paper is from 2005, meaning before the Lisbon Treaty was signed, the questions it raised are relevant even after its entry into force), basically concluding that the EU can still be considered as a sui generis entity with specific treaty-concluding ability. ${ }^{186}$ In this sense, the EU's participation in space (and for that matter any) activity at an international level, with an appropriate legal framework, does not cause any problems. What, on the other hand, does pose a problem is the question of cooperation amongst Member States in a common EU Space Programme since the responsibility falls, as stated, primarily on the states themselves. There is another Article, which is probably the most applicable to the EU. Although the EU is a sui generis entity, with many federal elements and certainly greater cooperation than other international organisations, for these purposes it could be considered as an intergovernmental organisation. Article 22 is concerned with the position of precisely these organisations in regard to liability for damages. There is, yet again, joint and several liability of the organisation and its Member States, but only if the claim for compensation is first presented to the organisation itself. If the organisation has not paid any sum in a period of six months, then the claim can be presented to the Member States (of course, only if the organisation itself becomes a party to the Convention and that the majority of the States members of the organisation are States Parties to the Convention on International Liability for Damage Caused by Space Objects and to the Outer Space Treaty). ${ }^{187}$ Even if the EU, as basically an intergovernmental organisation for these purposes, pays the relevant damages, it will still reflect on Member States, since they are the ones which finance the EU's activities. This means that it is essential, in order to resolve this, as has now been shown, primarily internal question, for legal action to be taken at the EU level.

Prior to studying the two possible solutions, one important disclaimer needs to be stated. These two 'approaches' are concerned exclusively with the question of liability and financial responsibility, not with the cooperation of Member States in the new Space Programme. The question of the approach which the EU took in the new Regulation with regards to the participation of Member States in the Programme will be discussed in the conclusion, since that is a question which we can, at least to a certain degree, actually answer. The two approaches regarding liability can be described as follows. Either every Member State, including the EU's frequent collaborator in the space sector, ESA (whose inclusion

${ }^{186}$ Duncan B Hollis, 'Why State Consent Still Matters: Non-State Actors, Treaties, and the Changing Sources of International Law' (2005) 23 Berkeley J Int Law 137, 160-161.

187 Outer Space Treaty, Art 22. 
also makes the situation even more complex, since it too is an intergovernmental organisation), would be responsible for possible damages, or, potentially, only those who were directly involved in, for example, an accident. Both options, however, have their pros and cons - the first one, a stronger approach, could be seen as being in accordance with the principle of solidarity, something which the EU is currently lacking in all areas, while at the same time pushing for with little success; the regulation would probably be much more straightforward; since all Member States financially (of course with regards to the principle of proportionality) contribute to the Space Programme through the EU budget (meaning those EUR 14.88 billion allocated for this purpose in the period between 2021 and 2027), and in this way participate in them at least indirectly, it would be logical that they all bear responsibility for any potential damage; the negative aspect would be that this would most likely cause internal tensions between Member States since their participation would probably greatly differ, while the principle of proportionality would at the same time be difficult to apply correctly. The second option, a much weaker approach, which would mean the liability of only the entities which had been directly and significantly involved in the development of a certain part of the Programme (eg a satellite, produced by ESA and with the human resources from some Member States, which collided with another space object and resulted in damage - then ESA and these Member States would be held liable for the damage) would remove the problem of unfair sharing of damages, but would also basically prevent the option of creating a 'common' policy in the true meaning of the word - the Programme would then be limited to nothing more than interstate cooperation, usually between the more developed Member States (and of course ESA). This approach would limit the possibilities of the EU as a leading actor in space activities in more than one way: 1) it would not utilise all the available resources, human ones being the most important (smaller states, such as Croatia, which have human, but not financial capacities, would most likely be excluded from all major projects); 2) incoherence would lead to major problems from the rationality perspective; 3) although the financial capacities of bigger states are strong enough for the bigger projects, ultimately the sharing of costs could still be seen as a firestarter for many of these projects, not only at a governmental level, but also as a way for citizens to view these projects as something which would not greatly hurt their economic power for activities with much more foreseeable results.

Returning to the question posed before the start of the previous paragraph, we can see that both options are possible in the context of international law. Although proportionality can be seen as a just way of resolving this problem, in reality this has rarely proven to be the case. 
It is simply too difficult to apply appropriately, and also opens the possibility of criticism, sometimes even unfounded, of the decisions of the relevant authorities. Obviously, this does not mean that a stronger approach is completely out of the question - this Regulation, as an agreement in its essence between Member States, could have established a similar method of apportioning, but failed to do so. In any case, as was put forward earlier, the question of the EU's liability for its space activities at an international level needs to be regulated internally. A stronger approach is what the authors of this paper propose, due to the negative consequences of the weaker approach, and despite the difficulties in the application of the principle of proportionality. These difficulties need to be overcome, and not only in this area if the EU wishes to continue towards the stronger cooperation of Member States, so this cannot be an excuse for the adoption of a weaker approach. In addition, since we have already established that the EU has ownership over the assets of the Programme, this also goes in favour of the argument for a stronger approach. Since the EU owns the assets, it should be liable and financially responsible, which means that all Member States should be held responsible since the EU is a single entity consisting of Member States, based on their mutual solidarity.

On the other hand, certain problems regarding liability can also arise from internal conflicts. Since there is no exclusive jurisdiction of the EU for space-related activities, national space programmes continue to exist. A problem could arise through a conflict between the EU Space Programme and a Member State space programme. This would happen, for example, in the case of a crash of a national satellite and an EU satellite. If a stronger approach regarding liability were accepted - in that case, if the EU's satellite was at fault for the crash, every Member State would be responsible for the damages caused, including the one whose national satellite was damaged. Even more problematic, if the fault was on both sides, then there would be the 'double' responsibility of one Member State (or more in the case of collaboration between multiple Member States outside the EU Space Programme, however unlikely that may be). At the EU level, two potential dispute resolution mechanisms could be implemented. The first could be a special ad-hoc body established for exactly these purposes. Just as the Convention establishes a special body the so-called 'Claims Commission' (consisting (usually) of three members, and whose decisions would be obligatory only if the disputing parties agree to it, otherwise it would be only recommended, although the States should consider it in good faith), ${ }^{188}$ the EU body should probably function

\footnotetext{
188 Resolution adopted by the General Assembly 2777 (XXVI), Convention on International Liability for Damage Caused by Space Objects, Arts 14-22 <www.unoosa.org/oosa/en/ourwork/spacelaw/treaties/liability-convention.html> accessed 15 August 2021.
} 
in the same way - it would be an ad hoc body whose members would be appointed by the disputing parties (if one of the parties were the EU itself, then an independent expert would have to be appointed), with the main difference being that its decisions would have to be mandatory, just as the decisions of the Court of Justice of the European Union are. The second option, a more straightforward one, would simply be to establish the jurisdiction of the Court of Justice of the EU in these matters. There are certainly arguments for and against both options. By establishing a special ad hoc body, there would be more space for amicable agreements, not necessarily based on the potential future legal framework. It would also prevent the further overloading of the Court, as well as ensuring that decision-making is in the hands of experts specialised in space law matters. On the other hand, the frequency with which these cases actually happen means that they would not overload the Court. In addition, the Court has so far shown its effectiveness in resolving even politically sensitive cases, a category into which these cases would most likely fall. Furthermore, the Court also has jurisdiction in cases regarding the liability of EUSPA, contractual and non-contractual, so why should this be an exception? In our opinion, the Court would be an appropriate dispute resolution mechanism. The formation of a special body of this kind seems unlikely, especially this early in the new Space Programme.

\subsection{Environmental aspect}

Although the Regulation covers some consequences which the Programme can have on the environment, some are still ignored. The SSA component (its SST sub-component to be more precise) is the one which is most concerned with this problem, but still falls short of what the optimal solution would be. Although space debris mitigation and remediation is one of the services of the SST sub-component, the Regulation does not provide any further information on how this should actually be done. It does state that the Commission can adopt implementing acts regulating the question of access to SST services and other relevant procedures, ${ }^{189}$ but is this enough? Satellites now constantly have to carry out collision avoidance manoeuvres, especially to avoid space debris. These are becoming increasingly common (with hundreds of these alerts every week), and, in addition to them being a significant financial burden, they represent a problem for the continuity of the provision of services. ${ }^{190}$ Even the

\footnotetext{
189 EU Space Regulation, Art 56(2).

190 ESA, 'Time to Act' <www.esa.int/ESA_Multimedia/Videos/2021/04/Time_to_Act> accessed 29 August 2021.
} 
smallest debris can cause significant problems. ${ }^{191}$ What makes the situation even more difficult is that the SSA and GOVSATCOM components have the least amount of funds allocated to them in the current budget (these components have a joint budget, different from the E-GNSS and Copernicus components, which have separate budgets), which is understandable, especially since GOVSATCOM is still in its very early phase, but we argue that there is no firm reason for such a disproportion between these components and the others. All other components of the Programme depend on the success of the removal and mitigation of space debris. Following from this, it is clear that the Regulation does not provide a sufficient legal framework for this problem. Of course, removing and preventing space debris is of a technical nature, but this does not mean that the Regulation should not describe the measures which need to be taken to establish a tangible obligation, and not only an abstract goal, which is what it currently does. And this could easily have been avoided - ESA, the EU's main partner in space-related activities, already concluded an agreement with the Swiss start-up ClearSpace in 2019 and plans to launch ClearSpace-1, the first space mission to remove debris from space, in 2025. ${ }^{192}$ The Regulation could have at least included a provision which would read as follows: 'The Commission shall conclude all relevant agreements with the ESA and other entities regarding the provision of space debris mitigation and remediation services of the SST sub-component'. It is true that this Regulation covers the period up to 2027, and that the ClearSpace-1 mission is the first of its kind and will be taken in 2025, meaning closer to the end of the current Programme's period of implementation, which does not mean that the EU should have waited for the next phase of its Programme. Once again, if it wants to be the global leader in space-related activities, it needs to set an example, not follow the steps of others.

\footnotetext{
191 'Due to relative orbital velocity of up to $56,000 \mathrm{~km} / \mathrm{h}$, centimetre-sized debris can seriously damage or disable an operational spacecraft. Collisions with an object larger than $10 \mathrm{~cm}$ will lead to catastrophic breakups, releasing hazardous debris clouds of which some fragments can cause further catastrophic collisions that may lead to an unstable debris environment in some orbit regions ("Kessler syndrome")'. See ESA, 8th European Conference on Space Debris <https://space-debris-conference.sdo.esoc.esa.int> accessed 29 August 2021.

192 'The ClearSpace- 1 mission will target the Vespa (Vega Secondary Payload Adapter) upper stage left in an approximately $800 \mathrm{~km}$ by $660 \mathrm{~km}$ altitude orbit after the second flight of ESA's Vega launcher back in 2013. With a mass of $100 \mathrm{~kg}$, the Vespa is close in size to a small satellite, while its relatively simple shape and sturdy construction make it a suitable first goal, before progressing to larger, more challenging captures by follow-up missions eventually including multi-object capture'. See ESA, ESA Commissions World's First Space Debris Removal <www.esa.int/Safety_Security/Clean_Space/ESA_commissions_world_s_ first_space_debris_removal> accessed 29 August 2021.
} 
Another problem which is becoming increasingly more significant is the problem of the physical characteristics of satellites. Due to the materials used, satellites reflect light - although this does not really pose an issue for the everyday person, since the satellites are still barely visible with the naked eye - it is troublesome for astronomical activities. The worry has increased exponentially in the last few years, mostly because of so-called 'megaconstellations' - networks of satellites, without any regulation of their brightness. ${ }^{193}$ Although so far there are no European companies that would launch these megaconstellations, this does not mean that there will not be any in the near future. Therefore, the EU needed to include provisions to impose certain restrictions to prevent EU-based companies, as well as those which provide services to EU citizens, from such activities. A report from the American Astronomical Society and NOIRLab has found that the impact of this problem could at least be reduced by launching fewer or no low Earth orbit (LEO) satellites, as well as those deployed at altitudes of more than around 600 $\mathrm{km}$, but also by darkening satellites by lowering their albedo and shading reflected sunlight. ${ }^{194}$ These findings could be a satisfactory basis for a legal framework, which the EU could adopt in the next phase of the Programme, in 2028.

\section{Concluding remarks}

In the analysis of the EU Space Regulation, as well as to a certain extent in the previous legal framework, the paper has given context to what the authors argue to be the three main problematic areas of the EU's space-related activities: their financing, scope, and public opinion on these activities. The new Regulation so far looks to be a mixed bag of results - in certain areas making great progress, whilst in others seemingly taking a short-sighted approach.

Financing, as always, poses the greatest problem. The new Regulation, as was shown in a separate subsection, does not do very much in this respect. This could be taken as a very strong argument for the opinion that the new Regulation will not be the necessary change the EU needs. It does introduce grants and prizes which, having in mind the sums which can be awarded, cannot be the foundation of any financially more exhaustive projects. As was mentioned previously through the ex-

\footnotetext{
${ }_{193}$ Alexandra Witze, 'How Satellite "Megaconstellations" Will Photobomb Astronomy Images' (Nature, 26 August 2021) <www.nature.com/articles/d41586-020-02480-5> accessed 29 August 2021. The problem has gained more traction mostly due to SpaceX's Starlink satellites.

${ }^{194}$ American Astronomical Society and NOIRLab, 'Impact of Satellite Constellations on Optical Astronomy and Recommendations Towards Mitigations' 5-6 <https://noirlab.edu/ public/media/archives/techdocs/pdf/techdoc003.pdf> accessed 29 August 2021.
} 
ample of Croatia, smaller Member States especially have the problem of securing funds from the dedicated budget, in addition to the complexity of the process of securing them, which has become notoriously slow and difficult. There is no need to question the requirement for detailed rules governing this procedure, but what we need to question is whether they are sometimes overly technical, which does not benefit the implementation of different projects, but actually raises obstacles. Although this can apply generally, it is painfully obvious in the segment which is the focus of the paper. Space-related activities are exceptionally complex, in addition to being sensitive to even the smallest changes, which makes it extremely difficult to predict their overall cost, as well as the final product. Defining these is one of the most important prerequisites for securing EU funding. Although there are different types of contracts which take into consideration these elements (conditional stage-payment and cost-reimbursement contracts being prime examples), these cannot eliminate the problems of the current financing procedure. A possible solution is obviously the simplification of tender financing through a result-oriented approach - the chosen tenderer would receive the funds in a not-so-strict procedure, but would then be subjected to evaluation stricter than that currently implemented. The received funds would then potentially have to be fully or partially returned, depending on the achieved results. This, of course, opens more space for different forms of abuse, but this should not be such a problem in this sector. Subjects participating in these activities are usually not the type to engage in such exploitation. Still, increased care is necessary. The financing procedure should therefore not remain intransigent, but should adapt to specific circumstances.

The new Regulation has expanded its reach by establishing GOVSATCOM as an additional component of the Space Programme, as well as by expanding the SSA component through the SWE and NEO sub-components. As was mentioned before, this initiative by the EU is certainly commendable. The EU has established arguably leading GNSS and Earth observation programmes, but some questions still need resolving at the legal level. The problem is that the Regulation simply falls short in certain areas, sometimes significantly so. General proclamations, primarily those concerning the environment, simply do not provide a sufficient basis for the undertaking of real steps in the remediation of space debris. Also, the new SWE and NEO sub-components of the SSA components are superficially regulated, which could slow their development. What presents itself as the most substantial issue, and which at the same time concerns all the activities in the Space Programme, is the lack of provisions concerning liability. The EU must not depend on the provisions of international law, whose efficiency has so far proven to be mixed at best (which applies generally to international law, not only the 
space law segment). Although a great deal has been done in the last decade, the job is far from finished. The Regulation which will be adopted in 2028 will certainly need to cover the legal vacuum of the current one.

Concerning public opinion on space-related activities, the EU's efforts have so far concentrated on the activities which have a direct impact on the everyday person's life - telecommunication, observatory activities, and location-based services. In these areas, the EU has accomplished many things - it has one of the most accurate GNSS and SBAS combinations (which has been implemented on almost all relevant devices), Copernicus is one of the (if not the) leading Earth observation programmes, ${ }^{195}$ all while taking further steps in the area of the security of highly sensitive information and the observation of the Earth's surroundings, through GOVSATCOM and SSA. Why, then, can the EU Space Programme be described as obscure in the general public's eye? Well, mostly because the EU does not have an awe-inspiring plan, such as sending a mission to another planet, or, at least, to the Moon, which other subjects mostly have. This does put the EU at a disadvantage in a sense. However, the EU does not currently need this, and it would probably not even be financially plausible. These programmes simply cost too much while usually being constantly delayed. It would only result in creating a negative view of the EU's spending in the public eye. This, however, does not mean that this should not be considered for the next phase of the Programme in 2028. We first need to concentrate on fixing existing problems on the Earth and then move to the next frontier. Therefore, the EU did not necessarily need to expand its Programme to new horizons, at least not in the period of 2021-2027, but to grow in the existing ones, while undertaking a planned, coherent and, in comparison to present efforts, a much more notable popularisation of the Programme and its benefits, which need to become visible to everyone. Only after success in this area can the EU think about expanding its activities in the aforementioned path. ${ }^{196}$ The Regulation, as a legal instrument,

\footnotetext{
195 Some others which should be mentioned are: the Landsat Programme, the oldest such programme launched through NASA and the United States Geological Survey's collaboration, which has so far launched eight satellites, with the launch of Landsat 9 at the time of writing planned for 23 September 2021, see <https://landsat.gsfc.nasa.gov> accessed 3 September 2021, along with the Suomi NPP satellite, which is a product of NASA, the National Oceanic and Atmospheric Administration, and the US Department of Defense's collaboration, see <www.nasa.gov/mission_pages/NPP/main/index.html > accessed 3 September 2021; and previously, ESA's Envisat satellite, which was the largest Earth observation spacecraft ever built, see <https://earth.esa.int/eogateway/missions/envisat> accessed 3 September 2021.

${ }^{196}$ In relation to the world's biggest space agency, NASA, the EU's budget for these activities can almost not be compared. NASA's budget for 2021 is $\$ 23.3$ billion, or around EUR 19.6 billion, while keeping in mind that it is growing every year, sometimes even by more than $\$ 1$ billion - see <www.planetary.org/space-policy/nasa-budget> accessed 4 September 2021.
} 
could not have accomplished this goal independently, since popularisation depends mostly on political activities, so in this sense there are no objections concerning the Regulation itself.

The Parliament and the Council have decided to take, through the current Regulation, an approach consistent with previous efforts in all areas of European integration. It is a continuation of historical institutionalism, since cooperation is slowly being extended to new areas of space-related activities, without changes which could be characterised as huge leaps, which would include the high degree of obligatory participation of all Member States. One of the Regulation's biggest contributions is the official creation of the EU Space Programme, which previously existed as different segments connected only by the common theme of space. Of course, the introduction of new components of the Programme is the most significant change, but that was to be expected from a new regulatory phase. But by formally creating a Space Programme, the Regulation provides the basis for something that is not its usual goal - popularisation. Although on paper the creation of a Space Programme which in essence existed even before 2021 does not represent a huge step, in reality it could lead to one. Now that the EU has a space programme, and is not only involved in different space-related projects, the public can see these activities as something that the EU has thought of to be deserving of a specialised budget and a coherent programme. This will enable greater steps to be taken in the future. In this sense, the Regulation can be described as a small step which could enable a giant leap in the near future - currently, it simply does not do enough to be defined as such. In any case, there are two possible courses of action. If the EU does take measures such as the ones recommended in this paper, the idea of the EU as a global leader can certainly come to life. On the other hand, if this process continues to lack the courage to take bigger, braver steps, the EU will get left behind by the rest of its competitors. We believe that the EU has this potential, but only time will tell whether we are right in our judgments.

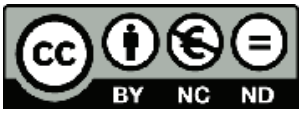

This work is licensed under the Creative Commons Attribution - Non-Commercial - No Derivatives 4.0 International License.

Suggested citation: L Orešković, S Grgić, 'The New EU Space Regulation: One Small Step or One Giant Leap for the EU?' (2021) 17 CYELP 77.

The EU's budget for these activities for the period 2021 to 2027, meaning seven years, is only EUR 14.88 billion. This makes missions such as searching for inhabitable planets basically impossible. Possible steps for the EU include expanding the budget and, what is also more likely, cooperation with other agencies, especially NASA. 